\title{
Zero Energy Ready Home Multifamily Case Study Analysis
}

Jordan Dentz and Kunal Alaigh Advanced Residential Integrated Energy Solutions Collaborative

February 2016 


\section{NOTICE}

This report was prepared as an account of work sponsored by an agency of the United States government. Neither the United States government nor any agency thereof, nor any of their employees, subcontractors, or affiliated partners makes any warranty, express or implied, or assumes any legal liability or responsibility for the accuracy, completeness, or usefulness of any information, apparatus, product, or process disclosed, or represents that its use would not infringe privately owned rights. Reference herein to any specific commercial product, process, or service by trade name, trademark, manufacturer, or otherwise does not necessarily constitute or imply its endorsement, recommendation, or favoring by the United States government or any agency thereof. The views and opinions of authors expressed herein do not necessarily state or reflect those of the United States government or any agency thereof.

Available electronically at SciTech Connect http:/www.osti.gov/scitech

Available for a processing fee to U.S. Department of Energy and its contractors, in paper, from:

U.S. Department of Energy

Office of Scientific and Technical Information

P.O. Box 62

Oak Ridge, TN 37831-0062

OSTI http://www.osti.gov

Phone: 865.576 .8401

Fax: 865.576.5728

Email: reports@osti.gov

Available for sale to the public, in paper, from:

U.S. Department of Commerce

National Technical Information Service

5301 Shawnee Road

Alexandria, VA 22312

NTIS http://www.ntis.gov

Phone: 800.553 .6847 or 703.605 .6000

Fax: 703.605.6900

Email: orders@ntis.gov 


\section{Zero Energy Ready Home Multifamily Case Study Analysis}

Prepared for:

The National Renewable Energy Laboratory

On behalf of the U.S. Department of Energy's Building America Program

Office of Energy Efficiency and Renewable Energy

15013 Denver West Parkway

Golden, CO 80401

NREL Contract No. DE-AC36-08GO28308

Prepared by:

Jordan Dentz and Kunal Alaigh

Advanced Residential Integrated Energy Solutions Collaborative

The Levy Partnership, Inc.

1776 Broadway, Suite 2205

New York, NY 10019

NREL Technical Monitor: Stacey Rothgeb

Prepared under Subcontract No. KNDJ-0-40347-05

February 2016 
The work presented in this report does not represent performance of any product relative to regulated minimum efficiency requirements.

The laboratory and/or field sites used for this work are not certified rating test facilities. The conditions and methods under which products were characterized for this work differ from standard rating conditions, as described.

Because the methods and conditions differ, the reported results are not comparable to rated product performance and should only be used to estimate performance under the measured conditions. 


\section{Contents}

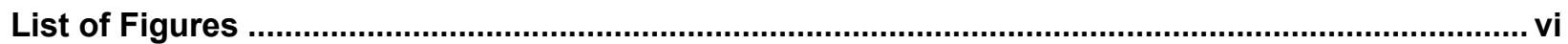

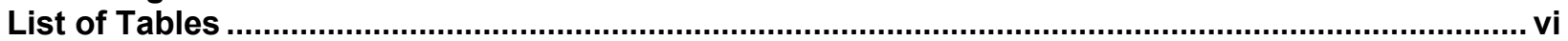

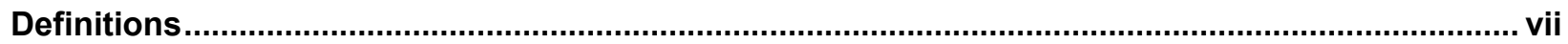

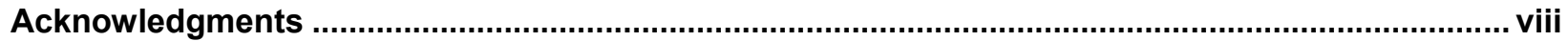

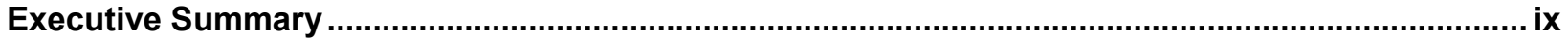

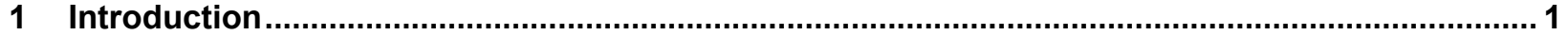

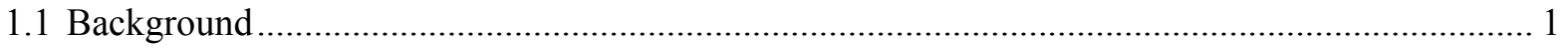

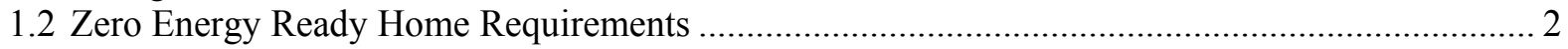

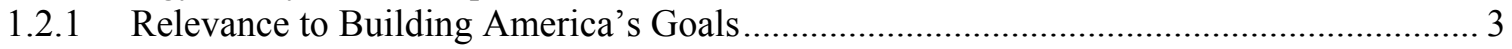

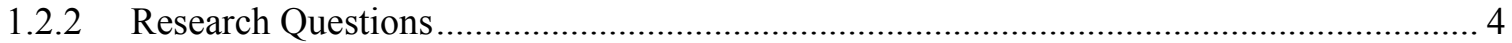

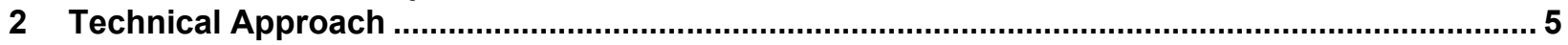

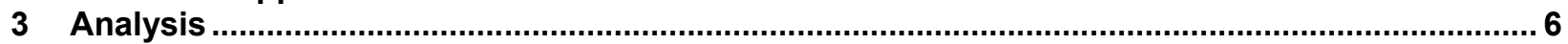

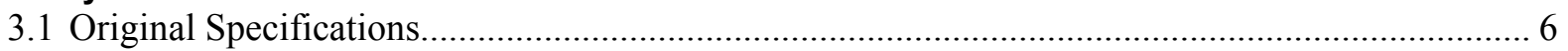

3.2 Zero Energy Ready Home Compliance ................................................................................. 7

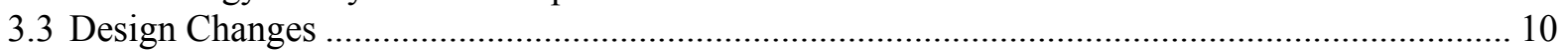

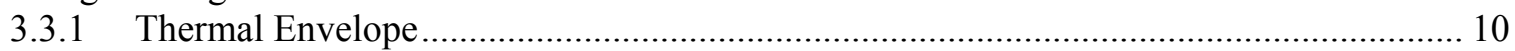

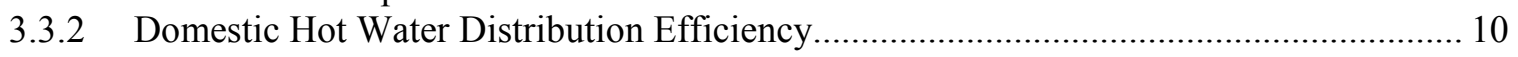

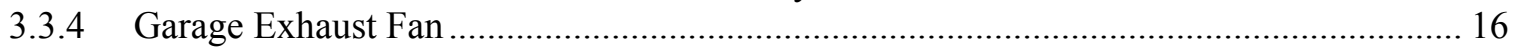

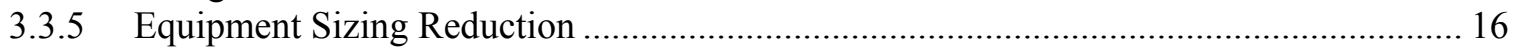

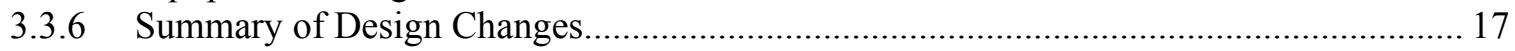

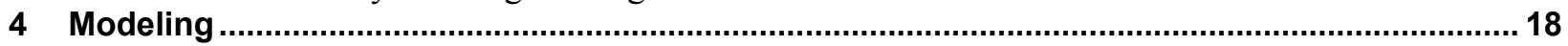

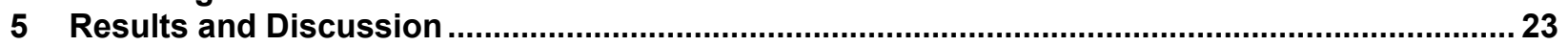

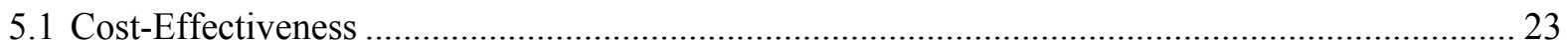

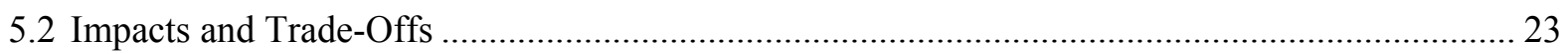

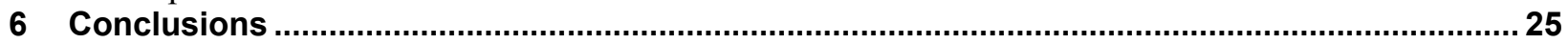

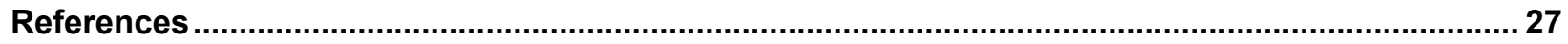

Appendix 


\section{List of Figures}

Figure 1. Avalon Green III under construction.

Figure 2. New privately owned housing units authorized by building permits in permit-issuing places-national

Figure 3. Two-bedroom apartment-water heater relocation.

Figure 4. Two-bedroom townhome-water heater relocation ...................................................... 11

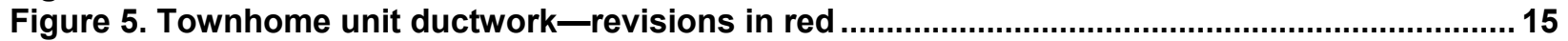

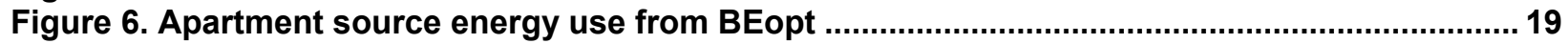

Figure 7. Townhome source energy use from BEopt ............................................................ 20

Figure 8. Apartment (single unit B4) annualized energy-related costs from BEopt ....................... 21

Figure 9. Townhome (single unit TC3) annualized energy-related costs from BEopt...................... 21

Unless otherwise noted, all figures were created by the ARIES team.

\section{List of Tables}

Table 1. ZERH Requirements 3

Table 2. ENERGY STAR Reference Design Compared to Original Specification-

Thermal Envelope.

Table 3. Original Specification-Equipment

Table 4. UA of Original Specifications Compared to ZERH .............................................................. 7

Table 5. Major ZERH Mandatory Requirements Compared to Original Design .................................. 8

Table 6. Major Indoor airPLUS Mandatory Requirements Compared to Original Design ................... 9

Table 7. Improvement to Whole-Envelope UA with Added Exterior Rigid Insulation ....................... 10

Table 8. Change in Vent and Heat Loop Piping Distance (in feet) and Cost Implications ............... 12

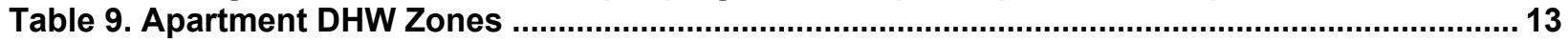

Table 10. Apartment DHW Distribution Water and Energy Waste per Year ..................................... 13

Table 11. Townhome DHW Zones (ZERH version) ........................................................................ 14

Table 12. Townhome DHW Distribution Water and Energy Waste per Year....................................... 14

Table 13. Space-Conditioning Equipment Sizing Reduction............................................................ 16

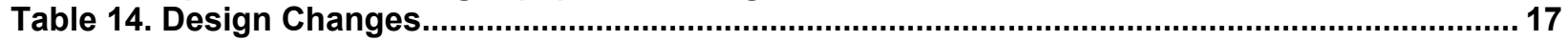

Table 15. Incremental Costs_Original Design to ZERH............................................................ 18

Table 16. Additional Incremental Costs_ENERGY STAR Version 3 Baseline to ZERH .................. 19

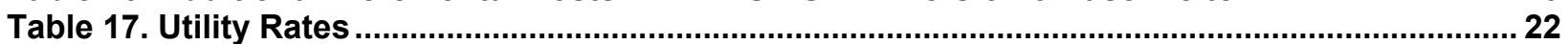

Table 18. Projected Annual Utility Bill Savings for the Original and ZERH Designs ........................22

Table 19. HERS Indices for Original and ZERH Designs ................................................................... 22

Table 20. Total Incremental Costs from Original Design to ZERH....................................................2 23

Table 21. Total Incremental Costs from ENERGY STAR Version 3 Minimum Design to ZERH........ 23

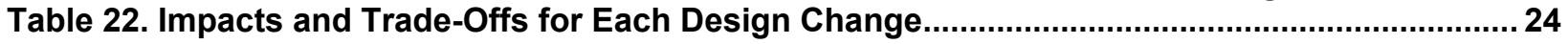

Table 23. Inputs and Results_DHW Distribution Waste_Apartment ........................................... 30

Table 24. Inputs and Results_DHW Distribution Waste-Townhome ......................................... 31

Unless otherwise noted, all tables were created by the ARIES team. 


\section{Definitions}

AFUE

ARIES

BEopt $^{\mathrm{TM}}$

BTU

CFL

CFM

DHW

DOE

$\mathrm{EF}$

EPA

HVAC

HERS

IECC

IEQ

MERV

NYSERDA

PEX

SEER

TO5

UA

ZERH
Annual Fuel Utilization Efficiency

Advanced Residential Integrated Energy Solutions

Collaborative Building America Team

Building Energy Optimization software

British Thermal Unit

Compact Fluorescent Lamp

Cubic Feet per Minute

Domestic Hot Water

U.S. Department of Energy

Energy Factor

Environmental Protection Agency

Heating Ventilating, and Air Conditioning

Home Energy Rating System

International Energy Conservation Code

Indoor Environmental Quality

Minimum Efficiency Reporting Value

New York State Energy Research and Development Authority

Cross-Linked Polyethylene

Seasonal Energy-Efficiency Ratio

Task Order 5

Area-Weighted Average Thermal Conductivity

Zero Energy Ready Home 


\section{Acknowledgments}

The authors would like to express their gratitude to Mitchel Forlenza and Aaron Levy of AvalonBay Communities for their assistance in facilitating this study. The authors also thank Michael Gestwick and Stacey Rothgeb of the National Renewable Energy Laboratory, who oversaw this work on behalf of the U.S. Department of Energy's Building America program. 


\section{Executive Summary}

The U.S. Department of Energy's Zero Energy Ready Home (ZERH) recognition program builds upon the building science requirements of ENERGY STAR ${ }^{\circledR}$ Certified Homes, Version 3 and best practices tested by the Building America research and demonstration program. The objectives of the ZERH criteria are to increase energy efficiency, improve indoor air quality, and prepare homes so renewable power can cost-effectively offset most or all of their annual energy consumption.

Multifamily units (units in buildings with five or more apartments) comprise an increasingly important segment in the U.S. new housing market. Over the past 30 years, this segment has averaged $24 \%$ of residential building permits and since the recession in 2008 averages $34 \%$ of new residential building permits (U.S. Census Bureau n.d.). AvalonBay Communities is a large multifamily developer that worked with the U.S. Department of Energy's Building America research team Advanced Residential Integrated Energy Solutions Collaborative (ARIES) to create a ZERH specification for a new development that was targeting ENERGY STAR certification.

ARIES undertook this research to analyze the cost, constructability, and energy implications of upgrading from ENERGY STAR to the ZERH specification for low-rise multifamily and attached housing units in climate zone 4 . The effort serves as an example of what multifamily builders can achieve and evaluates the mainstream viability of ZERH building practices. The team used Building Energy Optimization (BEopt ${ }^{\mathrm{TM}}$ ) software to select sample apartment units for energy modeling and cost analysis and to determine savings and construction cost increases compared to ENERGY STAR.

Starting from the original ENERGY STAR-compliant design (Version 3, Rev. 07), seven changes would need to be made in the sampled units to comply with ZERH criteria:

- Increase the exterior rigid insulation thickness from $1 / 2 \mathrm{in}$. to $1 \mathrm{in}$.

- Relocate the water heaters.

- Bring the ducts into a dropped soffit in townhome units.

- Upgrade to minimum efficiency reporting value 8 filters.

- Add rodent screens to vents.

- Protect and clean ducts.

- Install an exhaust fan in the garage of each townhome unit.

All these design upgrades could have been incorporated relatively easily any time before construction; however, the domestic hot water distribution and duct location changes would optimally be made during the design phase. Energy impacts of upgrading from the original design to ZERH included a reduction in source energy consumption of $2 \%-8 \%$ or $1.7-10.4$ $\mathrm{MBtu} /$ year. Because of local program requirements, the original design was already about $8 \%$ better than a design configured to minimum ENERGY STAR criteria. According to the BEopt analysis, annualized energy-related costs (the annual costs of all energy-related expenses 
including utilities, mortgages on equipment, etc. $)^{1}$ of the ZERH design were approximately $\$ 12$ lower for the apartment and approximately $\$ 134$ lower for the townhome than for the original design.

The residents pay for all utilities in these rental apartments, so the savings would accrue to the residents; the construction costs would be borne by the developer. The developer would be motivated to make these improvements only if they increased marketability, raised rents, increased occupant satisfaction, or reduced maintenance costs.

\footnotetext{
${ }^{1}$ BEopt calculates the annualized energy-related costs by annualizing the energy-related cash flows over the analysis period. Cash flows consist of mortgage or loan payments, replacement costs, utility bill payments, mortgage tax deductions (for new construction), and residual values. Costs, excluding mortgage or loan payments, are inflated based on the time they occur during the analysis period. The cash flows are annualized by determining the present worth of the cash flow by converting the total cost for each year to the value at the beginning of the analysis period (NREL 2012).
} 


\section{Introduction}

\subsection{Background}

The U.S. Department of Energy's (DOE's) Zero Energy Ready Home (ZERH) program recognizes builders for their leadership in increasing energy efficiency, improving indoor air quality, and making homes zero energy ready.

The program traces its roots to the DOE Builder's Challenge program, which was substantially revised and updated in early 2012 and renamed the DOE Challenge Home program. In summer 2014 it was again renamed the Zero Energy Ready Home program. It builds upon the building science requirements of ENERGY STAR ${ }^{B}$ Certified Homes, Version 3 and best practices tested by the Building America research and demonstration program. ZERH also incorporates the Environmental Protection Agency's (EPA's) Indoor airPLUS and WaterSense programs (EPA 2013a).

DOE Zero Energy Ready Homes are verified by a qualified third party and are intended to be at least $40 \%-50 \%$ more energy efficient than a typical new home that was built to code minimum. This generally corresponds to a Home Energy Rating System (HERS) Index Score in the low- to mid-50s depending on the home's size and location. The objective of the ZERH criteria is a set of building performance specifications that are so energy efficient that renewable power can cost-effectively offset most or all the annual energy consumption (DOE 2015).

The ZERH program is still in its infancy; market penetration is relatively slight and multifamily participation is negligible (Nebbia 2014). This is not unexpected at this early stage for a program that is a step above the more well-established ENERGY STAR New Homes program.

Potential barriers to achieving greater participation in the ZERH program include cost and constructability issues, which may differ based on climate region and building type. This report analyzes the cost, constructability, and energy implications of upgrading from ENERGY STAR to the ZERH specification for low-rise multifamily and attached housing units in climate zone 4 .

DOE's Building America research team Advanced Residential Integrated Energy Solutions Collaborative (ARIES) partnered with AvalonBay Communities (a large national property development, property management, and general contracting company) to develop a ZERH specification for a new low-rise multifamily development in New York State. AvalonBay owns and manages 82,576 housing units in 276 developments across the country. Each year the company builds numerous multifamily developments that it then operates as rental communities. Each development typically contains 100-400 apartment homes, townhomes, or some combination. The company has built or is developing nearly 50 Leadership in Energy \& Environmental Design- or ENERGY STAR-certified communities to date. The development that was analyzed in this case study is "Green III" in Elmhurst, New York, which is targeting ENERGY STAR certification and incentives through the New York State Energy Research and Development Authority (NYSERDA) Low-rise Residential New Construction Program. 


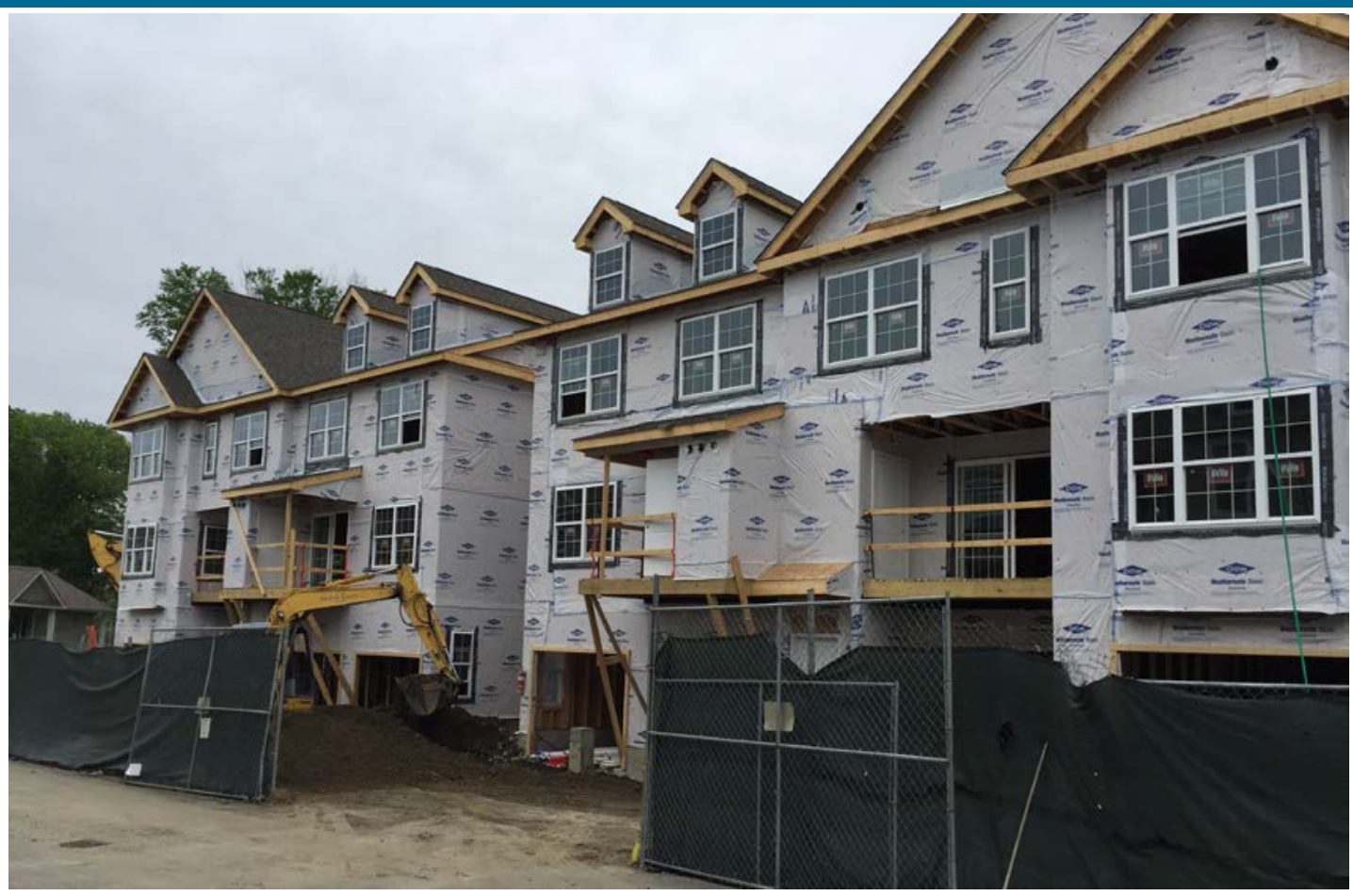

Figure 1. Avalon Green III under construction

The multifamily segment is becoming increasingly important in the new housing market.

Nationally, multifamily units (those in buildings with five or more apartments) comprised 34\% of new home permits in 2013 - the highest percentage since 1985. Over the past 30 years, this segment has averaged $24 \%$ of residential permits; the growth to the present ratio occurred since the 2008 recession (Figure 2) (U.S. Census Bureau 2008).
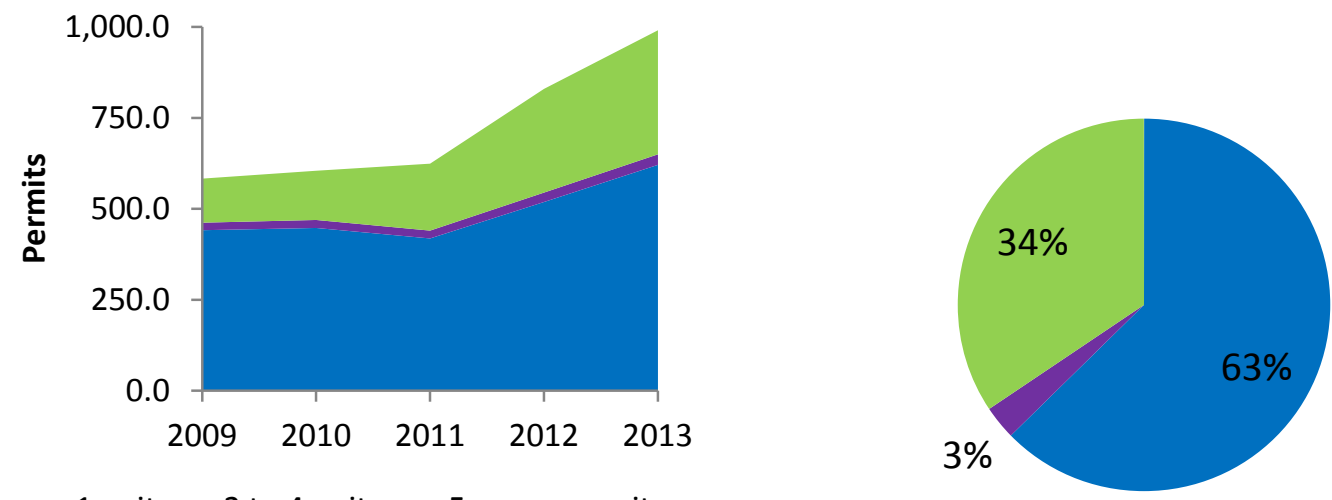

$\square$ unit $\square 2$ to 4 units $\quad 5$ or more units

Figure 2. New privately owned housing units authorized by building permits in permit-issuing places-national

\subsection{Zero Energy Ready Home Requirements}

DOE ZERH certification requires the home to qualify for EPA's ENERGY STAR label (Version 3 ) and EPA's Indoor airPLUS label. ENERGY STAR Version 3 requires insulation based on the 2009 International Energy Conservation Code (IECC). However, the ZERH program requires 
following the provisions of the 2012 IECC. The ZERH program includes provisions for energy efficiency, comfort, durability, and indoor air quality (DOE 2012). Basic requirements for ZERH certification are included in Table 1 (DOE 2014a).

Table 1. ZERH Requirements

\begin{tabular}{|c|c|}
\hline Area & Mandatory Requirements \\
\hline $\begin{array}{l}\text { ENERGY STAR } \\
\text { for Homes }\end{array}$ & Certified under ENERGY STAR Certified Homes Version 3 \\
\hline Envelope & $\begin{array}{c}\text { Fenestration meets or exceeds latest ENERGY STAR requirements } \\
\text { Ceiling, wall, floor, and slab insulation meets or exceeds } 2012 \text { IECC levels }\end{array}$ \\
\hline Duct System & Ducts located within the home's thermal and air barrier boundary \\
\hline Water Efficiency & $\begin{array}{c}\text { Hot water delivery systems shall meet efficient design requirements } \\
\text { (requires that the hot water distribution system stores no more than } 0.5 \text { gal } \\
\text { of water in any piping/manifold between the hot water source and any hot } \\
\text { water fixture) }\end{array}$ \\
\hline $\begin{array}{l}\text { Lighting and } \\
\text { Appliances }\end{array}$ & $\begin{array}{c}\text { All installed refrigerators, dishwashers, and clothes washers are } \\
\text { ENERGY STAR certified. } \\
\text { 80\% of lighting fixtures are ENERGY STAR certified or ENERGY STAR } \\
\text { lamps (bulbs) in minimum } 80 \% \text { of sockets } \\
\text { All installed bathroom ventilation and ceiling fans are } \\
\text { ENERGY STAR certified. }\end{array}$ \\
\hline Indoor airPLUS & $\begin{array}{l}\text { Certified under EPA Indoor airPLUS - includes provisions relating to } \\
\text { moisture control; pests; radon; heating, ventilating, and air conditioning } \\
\text { (HVAC); combustion pollutants; water management; and materials } \\
\text { emissions (EPA 2013a). }\end{array}$ \\
\hline Renewable Ready & $\begin{array}{l}\text { Consolidated Renewable Energy Ready Home Checklist completed. } \\
\text { Preparations for future photovoltaics array are required only if the location } \\
\text { has at least } 5 \mathrm{kWh} / \mathrm{m}^{2} / \text { day average daily solar radiation, the roof is not } \\
\text { shaded, and sufficient roof area is oriented within } 45^{\circ} \text { of south } \\
\text { (DOE 2015). }\end{array}$ \\
\hline
\end{tabular}

\subsubsection{Relevance to Building America's Goals}

By developing a prototype ZERH design for a typical multifamily development, this project addresses the following questions posed in the DOE Statement of Need (DOE 2014b):

- Can DOE Challenge [now ZERH] specifications be used by production builders to reliably deliver $30 \%$ homes to market [i.e., homes $30 \%$ more energy efficient than code]?

- How much more does a Challenge Home [now ZERH] cost to build compared with ENERGY STAR? 


\subsubsection{Research Questions}

This research will address the following questions:

1. What set of measures can successfully result in meeting ZERH specifications for a market rate multifamily project in climate zone 4 ?

2. What changes are required to upgrade a multifamily development from ENERGY STAR to ZERH? What design and construction approaches can help streamline the move to ZERH production?

3. What are the resulting costs to upgrade a multifamily development from ENERGY STAR to ZERH? Can any construction cost savings be captured if equipment needs are reduced?

4. What are the energy impacts of upgrading a multifamily development from ENERGY STAR to ZERH? Is it cost-effective as calculated via Building Energy Optimization (BEopt ${ }^{\mathrm{TM}}$ ) modeling? 


\section{Technical Approach}

The ARIES team took the following approach to answer the questions:

1. Analyze current specifications: Obtain plans and specifications for a planned multifamily development, compare them to the ZERH criteria, and identify required changes.

2. Develop proposed modifications: Collaborate with the developer to modify the specifications to develop a ZERH specification for the multifamily development.

3. Estimate upgrade costs: Estimate the costs of the ZERH upgrades compared to the current specifications.

4. Energy modeling: Create models of the original designand an ENERGY STAR Version 3 minimum and ZERH versions of representative housing units using BEopt (to evaluate annualized energy-related costs) and REM/Rate (to confirm ENERGY STAR and ZERH compliance).

The subject test case is a three-building addition to an existing 444-unit, 21-building development in Elmsford, New York. The three new buildings include 68 units: two apartment buildings of 30 units each and one eight-unit townhome building. 


\section{Analysis}

\subsection{Original Specifications}

The original development was designed to comply with ENERGY STAR Version 3 plus specific requirements imposed by NYSERDA to receive incentives under its Low-rise Residential New Construction Program. The additional NYSERDA requirements included minimum 90 annual fuel utilization efficiency (AFUE) space- and water-heating efficiency, minimum seasonal energy efficiency ratio (SEER) 14.5 cooling, maximum air infiltration of $0.30 \mathrm{CFM} 50 / \mathrm{ft}^{2}$ of enclosure surface area, and common area lighting and enclosure requirements (NYSERDA 2014). The original specifications and applicable ENERGY STAR Version 3 reference home specifications are shown in Table 2 for thermal envelope and Table 3 for equipment.

Table 2. ENERGY STAR Reference Design Compared to Original Specification-Thermal Envelope

\begin{tabular}{|c|c|c|c|}
\hline Feature & $\begin{array}{c}\text { ENERGY STAR } \\
\text { Version } 3 \text { Reference } \\
\text { Home }\end{array}$ & $\begin{array}{l}\text { Original Design- } \\
\text { Apartments }\end{array}$ & $\begin{array}{l}\text { Original Design- } \\
\text { Townhomes }\end{array}$ \\
\hline Slab Floor & $\begin{array}{l}\text { R-10 perimeter, } \\
2 \mathrm{ft} \text { deep }\end{array}$ & $\begin{array}{l}\text { R-15 rigid foam on slab } \\
\text { over garage }\end{array}$ & $\begin{array}{l}\text { R-10 perimeter, } \\
2 \mathrm{ft} \text { deep }\end{array}$ \\
\hline $\begin{array}{l}\text { Framed } \\
\text { Floor }\end{array}$ & R-30 grade 1 & N/A & $\begin{array}{l}\text { R-30 fiberglass batt } \\
\text { grade } 1 \text { above garage } \\
\text { and terrace }\end{array}$ \\
\hline $\begin{array}{c}\text { Above- } \\
\text { Grade Walls }\end{array}$ & $\begin{array}{l}\text { R-13 fiberglass batt }+ \\
\text { R-3 rigid } 2 \times 4 \\
\text { exterior walls }\end{array}$ & $\begin{array}{l}\mathrm{R}-15 \text { fiberglass batt }+ \\
\mathrm{R}-3 \text { rigid } 2 \times 4 \text { exterior } \\
\text { walls }\end{array}$ & $\begin{array}{c}\mathrm{R}-15 \mathrm{FG} \text { batt }+\mathrm{R}-3 \\
\text { rigid } 2 \times 4 \text { exterior } \\
\text { walls }\end{array}$ \\
\hline Windows & $\begin{array}{l}\mathrm{U}: 0.32 \text { SHGC: No } \\
\text { requirement }\end{array}$ & U: 0.32 SHGC: 0.40 & U: 0.32 SHGC: 0.40 \\
\hline Doors & No requirement & $\begin{array}{l}\text { No opaque exterior } \\
\text { doors to apartments }\end{array}$ & $\mathrm{R}-4.4$ \\
\hline Ceiling & $\mathrm{R}-38$ grade 1 & $\begin{array}{l}\text { R-38 fiberglass batt } \\
\text { grade } 1\end{array}$ & $\begin{array}{c}\text { R-30 fiberglass batt } \\
\text { grade } 1\end{array}$ \\
\hline Infiltration & 5 ACH50 & \multicolumn{2}{|c|}{$\begin{array}{c}\text { Maximum } 0.30 \mathrm{CFM} 50 / \mathrm{ft}^{2} \text { of enclosure surface } \\
\text { area per the NYSERDA Low-rise Residential } \\
\text { New Construction Program }\end{array}$} \\
\hline
\end{tabular}


Table 3. Original Specification-Equipment

\begin{tabular}{|c|c|c|}
\hline Feature & $\begin{array}{c}\text { ENERGY STAR } \\
\text { Version } 3 \text { Reference Home }\end{array}$ & Original Specification \\
\hline Space Heating & $\begin{array}{l}90 \text { AFUE or ENERGY } \\
\text { STAR certified }\end{array}$ & $\begin{array}{l}\text { Forced air system; heat provided by hot } \\
\text { water coil from tankless water heater - } \\
\qquad 96 \% \text { AFUE }\end{array}$ \\
\hline Space Cooling & $\begin{array}{l}\text { SEER } 13 \text { (NYSERDA } \\
\text { requires SEER 14.5) }\end{array}$ & 14.5 SEER split-system air conditioner \\
\hline Water Heating & $\begin{array}{l}0.61 \text { energy factor }(\mathrm{EF}) \text { for } \\
\text { instantaneous (tankless) }\end{array}$ & $0.96 \mathrm{EF}$ tankless water heater \\
\hline $\begin{array}{l}\text { Whole-House } \\
\text { Ventilation }\end{array}$ & $\begin{array}{c}\text { Designed and tested to } \\
\text { ASHRAE } 62.2\end{array}$ & $\begin{array}{l}\text { ENERGY STAR-certified bathroom } \\
\text { exhaust fan-continuous operation to } \\
\text { ASHRAE } 62.2\end{array}$ \\
\hline Appliances & ENERGY STAR certified & ENERGY STAR certified \\
\hline Lighting & $\begin{array}{c}\text { Minimum } 80 \% \text { ENERGY } \\
\text { STAR certified }\end{array}$ & $\begin{array}{c}\text { Minimum } 80 \% \text { ENERGY STAR } \\
\text { certified }\end{array}$ \\
\hline
\end{tabular}

\subsection{Zero Energy Ready Home Compliance}

A home may comply with ZERH requirements through either the performance or the prescriptive path. The ZERH performance path requires that the thermal enclosure area-weighted average thermal conductivity, known as $U A$, meet the requirements of the 2012 IECC. When considering $\mathrm{U}$ values, a lower number results in less heat transfer, so the designed UA must be equal to or lower than the UA that would result from the prescriptive 2012 IECC insulation values (this is the "equivalent UA approach" (ICC 2012). UA values were calculated for one sample townhome (plan TC3) and one sample apartment (plan B4A). Both the apartment and townhome required a slight improvement in UA (Table 4). Table 4 also shows the UA for the ENERGY STAR Version 3 reference home.

Table 4. UA of Original Specifications Compared to ZERH

\begin{tabular}{c|c|c|c}
\hline & $\begin{array}{c}\text { ENERGY STAR Version } \\
\text { 3 Reference Design (using } \\
\text { prescriptive IECC 2009 } \\
\text { insulation values) }\end{array}$ & Original Design & $\begin{array}{c}\text { ZERH (using } \\
\text { prescriptive IECC 2012 } \\
\text { insulation values) }\end{array}$ \\
\hline Apartment & 205 & 202.8 & 197.8 \\
Townhome & 299 & 286.1 & 278.6 \\
\hline
\end{tabular}

ZERH also contains mandatory requirements that are not required by ENERGY STAR. A summary as it pertains to this project is shown in Table 5 and Table 6. A number of upgrades, including pest prevention, duct protection, filtration, garage exhaust, preoccupancy flush, duct location, and domestic hot water (DHW) distribution system efficiency, were required to meet these mandatory requirements. 
Table 5. Major ZERH Mandatory Requirements Compared to Original Design

\begin{tabular}{|c|c|c|}
\hline Item & Requirement & $\begin{array}{l}\text { Original Design } \\
\text { Complies? }\end{array}$ \\
\hline Duct Systems & $\begin{array}{l}\text { Ducts located within home's thermal and air } \\
\text { barrier boundary or encapsulate with spray } \\
\text { foam and cover with blow-in cellulose/ } \\
\text { fiberglass (some exceptions allowable) }\end{array}$ & $\begin{array}{l}\text { No (townhomes); } \\
\text { Yes (apartments) }\end{array}$ \\
\hline $\begin{array}{l}\text { Water } \\
\text { Distribution } \\
\text { Efficiency }\end{array}$ & $\begin{array}{l}\text { The DHW distribution system shall store no } \\
\text { more than } 0.5 \text { gal of water in any piping/ } \\
\text { manifold between the hot water source and } \\
\text { fixture. In the case of occupant-controlled or } \\
\text { occupancy sensor-based recirculation systems, } \\
\text { the storage limit is measured from the point } \\
\text { where the branch feeding the fixture branches } \\
\text { off the recirculation loop, to the fixture. }\end{array}$ & No \\
\hline Appliances & $\begin{array}{l}\text { All installed refrigerators, dishwashers, and } \\
\text { clothes washers are ENERGY STAR certified }\end{array}$ & Yes \\
\hline $\begin{array}{l}\text { Renewable } \\
\text { Ready }\end{array}$ & Renewable Energy Ready Home checklist & $\begin{array}{l}\text { Not applicable for this } \\
\text { location due to insufficient } \\
\text { solar radiation }\end{array}$ \\
\hline
\end{tabular}




\begin{tabular}{|c|c|c|}
\hline Item & Requirement & $\begin{array}{c}\text { Original Design } \\
\text { Complies? }\end{array}$ \\
\hline Moisture Control & $\begin{array}{l}\text { Hard surface flooring in kitchens, baths, entry, laundry and utility rooms, and piping } \\
\text { in exterior walls insulated with pipe wrap }\end{array}$ & Yes \\
\hline Pests & $\begin{array}{c}\text { Corrosion-proof rodent/bird screenings installed at all openings that cannot be } \\
\text { sealed (exception: dryer vents) }\end{array}$ & No \\
\hline HVAC Systems & $\begin{array}{l}\text { Duct systems protected from construction debris and no building cavities used as } \\
\text { supplies or returns } \\
\text { No air-handling equipment or ductwork installed in garage and continuous air } \\
\text { barrier in adjacent assemblies } \\
\text { Central forced air systems have minimum efficiency reporting value (MERV) } 8 \text { and } \\
\text { no ozone generators in home } \\
\text { Carbon monoxide alarms installed in each sleeping zone (e.g. common hallway) } \\
\text { according to National Fire Protection Association } 720 \\
\text { Multifamily buildings: Smoking restrictions implemented and Environmental } \\
\text { Tobacco Smoke transfer pathways limited } \\
\text { Townhomes: Door closer installed on all connecting doors; in homes with exhaust- } \\
\text { only whole-house ventilation (e.g., bath fans), either a 70-CFM exhaust fan installed } \\
\text { in the garage or pressure test conducted to verify the effectiveness of the garage-to- } \\
\text { house air barrier }\end{array}$ & $\begin{array}{l}\text { No } \\
\text { Yes } \\
\text { No } \\
\text { Yes } \\
\text { Yes }\end{array}$ \\
\hline Materials & $\begin{array}{c}\text { Certified low-formaldehyde composite wood materials and structural plywood and } \\
\text { oriented strand board PS1 or PS2 compliant } \\
\text { Certified low- or no-volatile organic compound interior paints and finishes used } \\
\text { Carpet, carpet adhesives Carpet and Rug Institute Green Label Plus and carpet } \\
\text { cushion Carpet and Rug Institute Green Label }\end{array}$ & $\begin{array}{l}\text { Yes } \\
\text { Yes } \\
\text { Yes }\end{array}$ \\
\hline Final Inspection & $\begin{array}{l}\text { HVAC system and ductwork verified to be dry and clean and new filter installed } \\
\text { Home ventilated before occupancy }\end{array}$ & $\begin{array}{l}\text { No } \\
\text { No }\end{array}$ \\
\hline
\end{tabular}




\subsection{Design Changes}

\subsubsection{Thermal Envelope}

The ZERH design required an approximately $2 \%-3 \%$ reduction in UA. This could be achieved by improvements to any exterior surfaces—walls, slab/floors, ceiling/roof, or windows.

Improvements to the ceiling/roof or floor/slab would not have affected lower and upper floor apartments, respectively, and the amount of additional insulation would not have been practical in all cases given the planned structure. Improvement to the window U-value would have forced the windows into another cost category and required using a different supplier, which was undesirable for the builder. Improvements to the walls were determined to be the most practical. The planned exterior wall construction was R-15 fiberglass batts in a $2 \times 4$ wall cavity plus R-3 rigid exterior insulation. Upgrading the exterior rigid insulation to R-6 would provide the necessary improvement (Table 7).

Table 7. Improvement to Whole-Envelope UA with Added Exterior Rigid Insulation

\begin{tabular}{c|c|c|c}
\hline & $\begin{array}{c}\text { Original Design UA } \\
\text { (R-3 insulating } \\
\text { sheathing) }\end{array}$ & $\begin{array}{c}\text { Original Design UA } \\
\text { with R-6 Insulating } \\
\text { Sheathing }\end{array}$ & $\begin{array}{c}\text { Target UA for ZERH } \\
\text { Compliance (using } \\
\text { prescriptive IECC 2012 } \\
\text { insulation values) }\end{array}$ \\
\hline Apartment & 202.8 & 195.1 & 197.8 \\
\hline Townhome & 286.1 & 272.6 & 278.6 \\
\hline
\end{tabular}

\subsubsection{Domestic Hot Water Distribution Efficiency}

Neither sample unit complies with the ZERH DHW distribution efficiency requirements as originally designed; both have pipe runs that exceed the 0.5 -gal storage limit from the water heater to the farthest fixture.

Compliance could be achieved by adding an on-demand hot water recirculation system with occupancy sensors that activate the hot water when the occupant enters the room. This could be considered where moving the heater is not practical; however, the team decided to explore reducing the pipe water volume.

Reducing all DHW pipe runs to no more than 0.5 gal would require some combination of reduced pipe diameters (perhaps in conjunction with the use of a plumbing manifold system to maintain adequate flows) and/or plan revisions to bring the end fixtures and water heater closer together. The smallest impact on the designs would be to move the water heater to a more central location in the floor plan -ideally in a closet or service space. Typically the water heater (which also provides space heating via a hot water loop to the air handling unit) is located adjacent to an outside wall to minimize vent pipe length. Moving the water heater to a more central location would have the additional benefit of moving it closer to the air handling unit to reduce heat loop pipe runs and associated heat losses. Figure 3 and Figure 4 show the original and proposed locations of the water heaters in relationship to end-use fixtures and the air handling unit for the sample apartment and townhome, respectively. Table 8 quantifies the change in pipe and vent run distances that resulted from the relocation and the associated first costs (about $\$ 68$ for the apartment and $\$ 110$ for the townhome). Pipe length from the water heater to the fixtures would be decreased; however, the combustion vent length would increase (a 1/4-in./ft pitch to the outside 
would be maintained). The length of the cold water main line may change to reach the new location; the gas regulator vent would have to be extended to the outside.

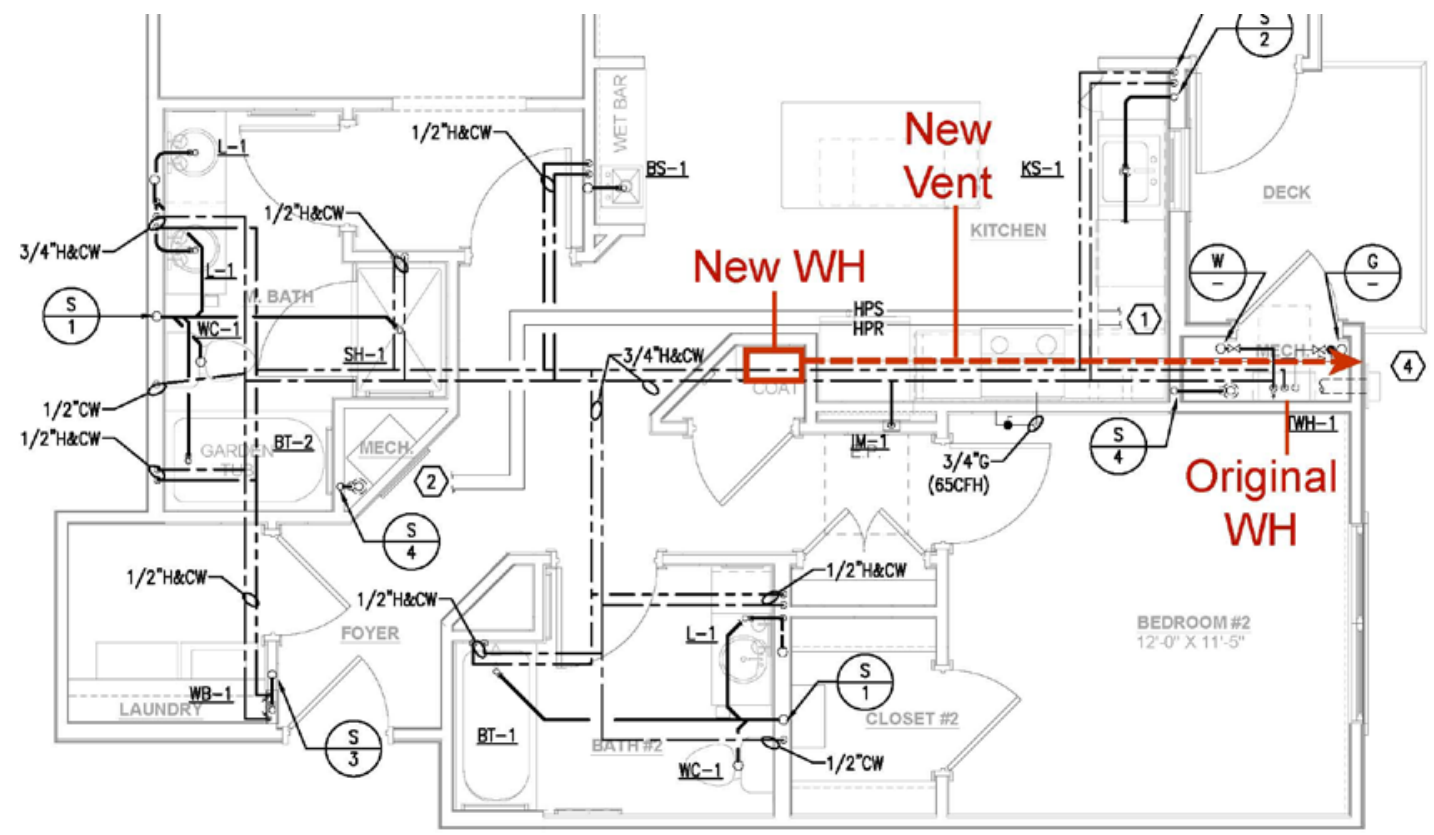

Figure 3. Two-bedroom apartment-water heater relocation
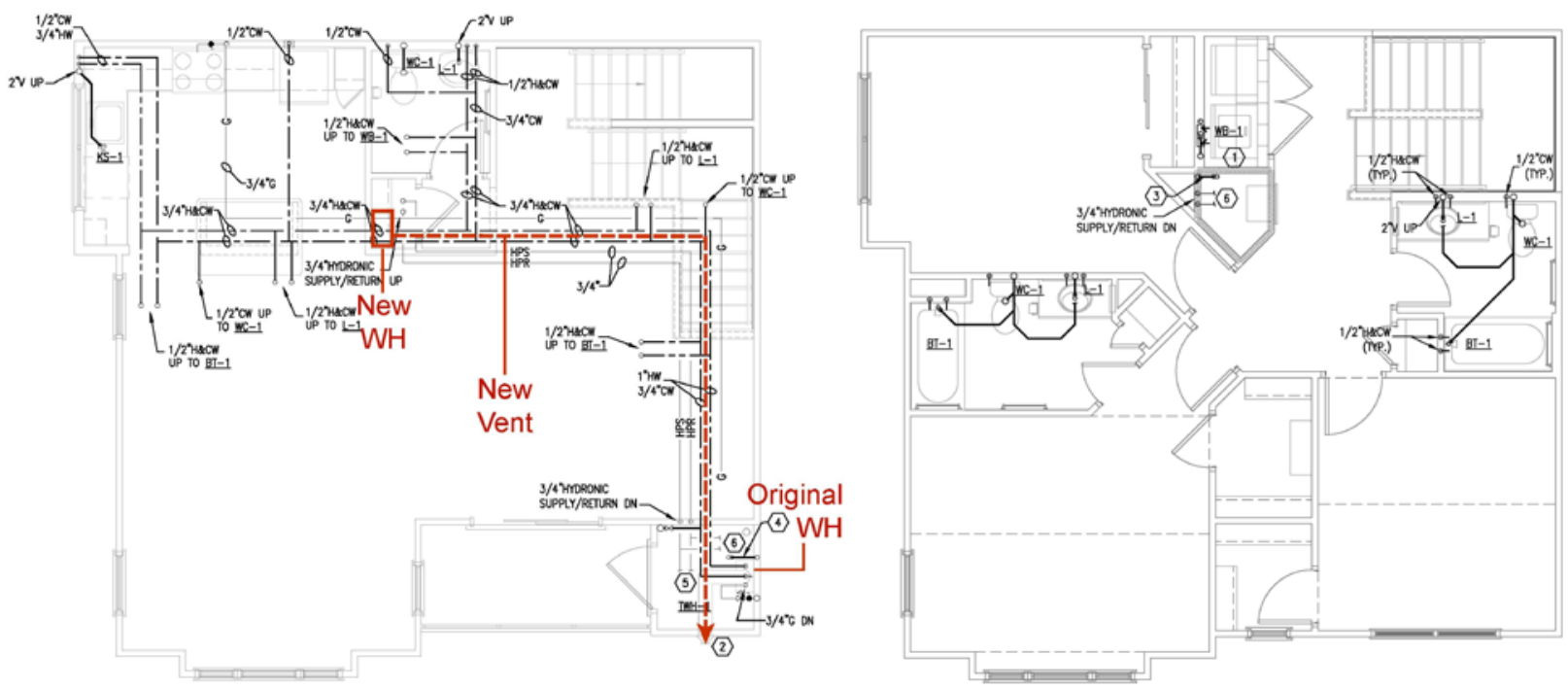

Figure 4. Two-bedroom townhome-water heater relocation 
Table 8. Change in Vent and Heat Loop Piping Distance (in feet) and Cost Implications

\begin{tabular}{|c|c|c|c|c|c|c|c|c|c|c|}
\hline & \multicolumn{3}{|c|}{ Original } & \multicolumn{3}{|c|}{ Modified } & \multicolumn{3}{|c|}{ Difference } & \multirow{2}{*}{$\begin{array}{c}\text { Pipe Cost } \\
\text { Difference } \\
\text { (\$) }\end{array}$} \\
\hline & Vent & $\begin{array}{l}\text { Heat } \\
\text { Loop }\end{array}$ & $\begin{array}{c}\text { DHW } \\
\text { Pipe }\end{array}$ & Vent & $\begin{array}{l}\text { Heat } \\
\text { Loop }\end{array}$ & $\begin{array}{c}\text { DHW } \\
\text { Pipe }\end{array}$ & Vent & $\begin{array}{l}\text { Heat } \\
\text { Loop }\end{array}$ & $\begin{array}{c}\text { DHW } \\
\text { Pipe }\end{array}$ & \\
\hline Apartment & 1 & 29 & 82 & 17 & 12 & 74 & +16 & -13 & -8 & $+\$ 67.95$ \\
\hline Townhome & 5 & 39 & 103 & 35 & 5 & 72 & +30 & -34 & -31 & $+\$ 110.20$ \\
\hline
\end{tabular}

Vent material cost: $\$ 4 / \mathrm{ft}$.

Heat loop and DHW pipe: $\$ 0.21 / \mathrm{ft}$. of $1 / 2$-in. diameter; $\$ 0.38 / \mathrm{ft}$ of $3 / 4$-in. diameter; $\$ 1.10 / \mathrm{ft}$ of 1 -in. diameter. Regulator vent line (3/8-in. copper): \$1/ft.

The water heater can be moved from an exterior location to an interior closet with a sealed combustion/condensing heater, however, certain precautions are advisable. According to the 2010 New York Plumbing Code any water heater that uses a solid or gas as a fuel cannot be installed within a bathroom, bedroom, or in a bedroom closet for which the only access is via a bedroom or bathroom. Only direct-vented water heaters are exceptions (ICC 2007). Other best practices include weather-stripping the door to the living space to prevent any combustion byproducts from infiltrating the living space and using fire-retardant cement backerboard in the closet. The local code official will have the final say about the permissibility of the new location.

The National Renewable Energy Laboratory's DHW Draw Profile Generation tool is an Excel spreadsheet-based DHW event generator ${ }^{2}$ that can be used to simulate hot water draw events (Hendron et al. 2010). It can generate annual DHW use data with resolution from a 1-second to a 6-minute time step and account for incoming cold water temperature variations by climate.

The tool was used to estimate the impact on water and energy consumption of the DWH distribution system redesign in response to the need to comply with ZERH criteria. LaGuardia, New York, climate data were used to generate an annual draw profile for a two-bedroom and a three-bedroom unit. The annual number of draws by fixture (or group of nearby fixtures, here termed a zone [Table 9]) was summed. Draws that occurred less than 10 minutes after a draw by the same fixture (or a fixture within the same zone) were eliminated, because the water was assumed to be still warm enough for use. The 10-minute threshold was determined by calculating the time for $125^{\circ} \mathrm{F}$ water to cool to $105^{\circ} \mathrm{F}$ in uninsulated .075 -in.-diameter cross-linked polyethylene (PEX) pipe (see Appendix A for calculation details). Also, draws of shorter duration than the time the water would take to travel from the water heater to the primary fixture (assuming maximum flow rate for the respective fixture type per federal standards and the respective pipe diameter) were not counted, because full service temperature was assumed to be unnecessary for these draws. The dishwasher and washing machine draws were not counted, because ZERH does not impose this requirement on appliances (they do not typically wait for, and therefore waste, hot water); however, draws from these appliances were considered in the 10-minute wait time (i.e., draws from fixtures in the same zones as these appliances were not counted if they followed them by less than 10 minutes).

\footnotetext{
${ }^{2}$ The DHW draw generator may be found at

https://buildingsfieldtest.nrel.gov/domestic_hot_water_dhw_draw_profile_generation
} 
Table 9. Apartment DHW Zones

\begin{tabular}{c|c}
\hline Zone & Fixtures \\
\hline $\mathbf{1}$ & Kitchen sink, dishwasher \\
$\mathbf{2}$ & Master bathtub, master bath lavatories, master bath shower \\
$\mathbf{3}$ & Bathroom 2 bathtub, bathroom 2 shower, bathroom 2 lavatory, \\
$\mathbf{4}$ & washing machine \\
\hline
\end{tabular}

Summing the resulting number of counted draws for the year for each hot water fixture zone and multiplying each by the pipe volume from the water heater to the fixture and by the ratio of hot to cold water as predicted by the draw calculator results in the annual water wasted while waiting for hot water. To calculate the energy in this wasted hot water, a temperature rise was determined for each draw based on the difference between the average incoming cold water temperature (from the National Renewable Energy Laboratory's draw generator) and the $125^{\circ} \mathrm{F}$ supply temperature, and the efficiency of the water heater (0.96 EF). See Appendix A for the draw profile, associated assumptions, and energy calculations. The results of the calculations are provided in Table 10 and Table 12.

Table 10. Apartment DHW Distribution Water and Energy Waste per Year

\begin{tabular}{|c|c|c|c|c|c|c|c|c|c|}
\hline \multirow[b]{2}{*}{ Zone } & \multirow[b]{2}{*}{ 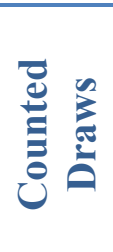 } & \multicolumn{3}{|c|}{ Original Location } & \multicolumn{3}{|c|}{ ZERH Location } & \multirow[b]{2}{*}{ 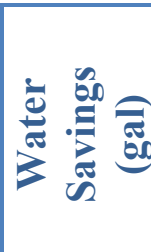 } & \multirow[b]{2}{*}{ 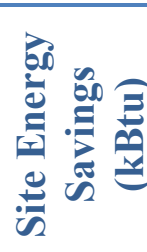 } \\
\hline & & 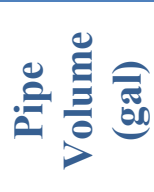 & 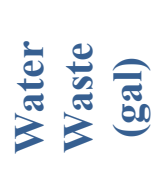 & 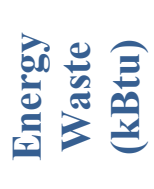 & 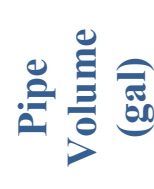 & 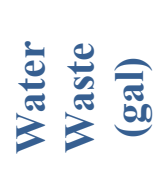 & 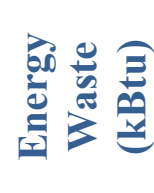 & & \\
\hline 1 & 2,773 & 0.54 & 1,118 & 643 & 0.44 & 896 & 515 & 291 & 128 \\
\hline 2 & 788 & 1.08 & 342 & 197 & 0.48 & 204 & 117 & 331 & 79 \\
\hline 3 & 447 & 0.66 & 280 & 160 & 0.33 & 137 & 78.7 & 190 & 82 \\
\hline 4 & 535 & 0.66 & 448 & 257 & 0.22 & 191 & 109 & 230 & 148 \\
\hline Totals & 4543 & & 2,188 & 1,258 & & 1,428 & 820 & 1,042 & 437 \\
\hline
\end{tabular}

The original plumbing layout for the townhome included a long run of 1-in. diameter DHW pipe from the water heater through the unit to the center of the first floor, where it then divided into smaller branch lines. Because most of the DHW was in this common trunk line a simplifying and conservative (in the sense of estimating savings) assumption was made to group all fixtures into one zone for the original energy/water waste calculations; i.e., any draw from any fixture was considered to recharge the entire system. Therefore Table 11 and Table 12 show a single zone for the original location, and three zones for the compliant location. This results in slightly fewer counted draws for the original configuration than the ZERH location, because no draw that follows another draw by less than 10 minutes for any fixture in the townhome is counted. 
Table 11. Townhome DHW Zones (ZERH version)

\begin{tabular}{c|c}
\hline Zone & Fixtures \\
\hline $\mathbf{1}$ & Kitchen sink, dishwasher, master bathtub, master bath sink, master bath shower \\
$\mathbf{2}$ & Powder room sink, clothes washer \\
$\mathbf{3}$ & Bathroom 2 bathtub, bathroom 2 shower, bathroom 2 sink \\
\hline
\end{tabular}

Table 12. Townhome DHW Distribution Water and Energy Waste per Year

\begin{tabular}{|c|c|c|c|c|c|c|c|c|c|}
\hline \multirow[b]{2}{*}{ Zone } & \multirow[b]{2}{*}{ 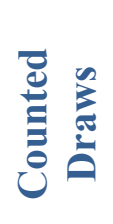 } & \multicolumn{3}{|c|}{ Original Location } & \multicolumn{3}{|c|}{ Compliant Location } & \multirow[b]{2}{*}{$\begin{array}{c}\text { Water } \\
\text { Savings } \\
\text { (gal) }\end{array}$} & \multirow[b]{2}{*}{$\begin{array}{c}\text { Site } \\
\text { Energy } \\
\text { Savings } \\
\text { (kBtu) }\end{array}$} \\
\hline & & 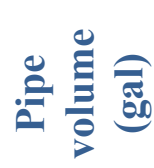 & 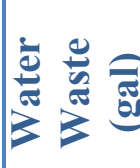 & 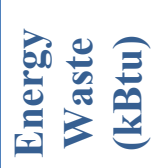 & 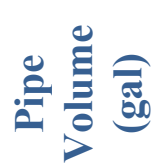 & 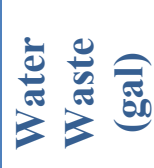 & 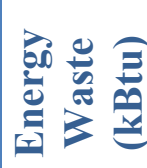 & & \\
\hline $\begin{array}{c}\text { All } \\
\text { (original } \\
\text { design) }\end{array}$ & 2,187 & 1.8 & 1,212 & 697 & N/A & N/A & N/A & & \\
\hline 1 & 2,123 & $\mathrm{~N} / \mathrm{A}$ & $\mathrm{N} / \mathrm{A}$ & N/A & 0.48 & 497 & 286 & & \\
\hline 2 & 294 & $\mathrm{~N} / \mathrm{A}$ & N/A & N/A & 0.28 & 72 & 41 & & \\
\hline 3 & 362 & $\mathrm{~N} / \mathrm{A}$ & $\mathrm{N} / \mathrm{A}$ & $\mathrm{N} / \mathrm{A}$ & 0.17 & 109 & 63 & & \\
\hline Totals & & & 1,212 & 697 & & 678 & 390 & 652 & 307 \\
\hline
\end{tabular}

The annual energy and water savings that accrue from the water heater relocation is estimated to be $436 \mathrm{kBtu}(5 \%)$ and 1,042 gal for the apartment and $307 \mathrm{kBtu}(3 \%)$ and 652 gal for the townhome. If a recirculating system were used instead, the water and energy savings would differ.

This is a rough estimate, because the zoning of fixtures is imperfect and temperatures are idealized. Also, DHW radiative heat loss within the conditioned space contributes to space heating and exacerbates cooling loads. These interactive effects are not considered here but can be significant (they have been estimated at 20\%-40\% of DHW distribution energy savings for multifamily recirculating systems using pump controls (Dentz et al. 2015)). Despite these limitations, this is a reasonable range of energy and water savings from the ZERH DHW distribution efficiency requirement for these homes.

\subsubsection{Ducts in Conditioned Space}

A home must meet the following conditions to comply with ZERH:

- No more than $10 \mathrm{ft}$ of forced-air ducts may be outside the thermal and air barrier boundary, unless

- The ducts are in an unvented attic (even if not conditioned with a supply register) or

- For climate zone 4A ducts in a vented attic have a minimum R-8 duct insulation plus a minimum 1.5 in. of closed-cell spray foam insulation encapsulating the ducts and 
0 the ducts are buried under at least 2 in. of blown-in attic insulation and

○ Total duct leakage is no more than 3 CFM25/100 $\mathrm{ft}^{2}$ of conditioned floor area.

- In all cases the HVAC equipment must still be located within the home's thermal and air barrier boundary.

The ductwork for the apartment units was designed wholly within the conditioned space; the flat roofs enclose an unvented attic cavity with a dropped ceiling below. However, part of the duct system in the townhome passes through the unconditioned vented attic.

The team determined that most practical approach to complying with these criteria in the townhome would be to bring the ducts into a furred-down soffit under the ceiling, rather than bringing in an additional subcontractor to apply the spray foam and relying on the lower duct leakage. This would require a soffit in the second-floor center hallway and master bedroom closet (Figure 5). The soffit framing cost was estimated at $\$ 100$ extra per townhome, but the reduced ductwork was estimated to save $\$ 82.50$; these costs are relatively low because of the high material volumes and production nature of the construction.

Figure 5 is a conceptual schematic of the revised duct design_-registers would need to be designed and located for proper air throw into the room and to avoid short-circuiting to return air pathways. Note that moving the supply registers away from their original location on the exterior walls above windows and to the interior walls could create comfort issues. As cold air infiltrates near window openings, occupants may feel a difference in temperature across the room. Improved envelope insulation and airtightness would be required to mitigate this issue. Other Building America teams have written extensively about compact air distribution systems (Burdick 2013).

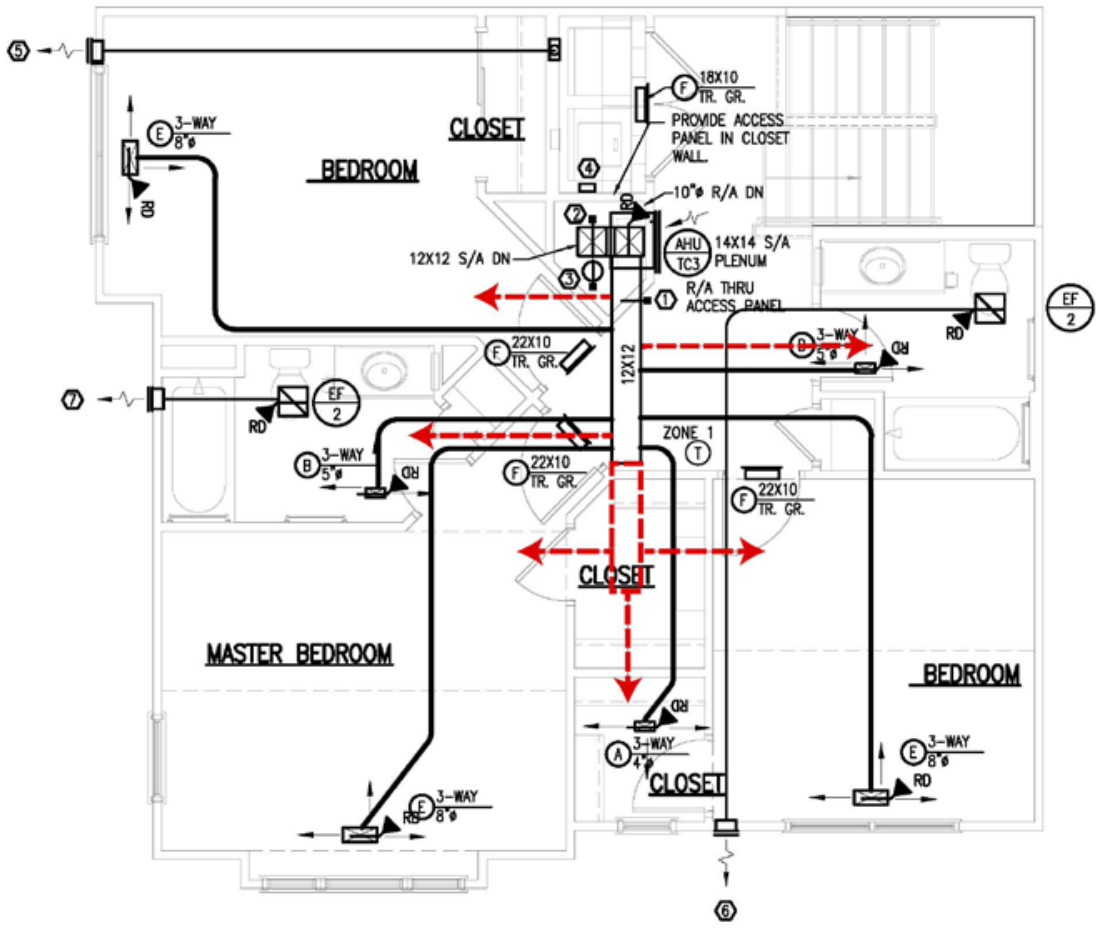

Figure 5. Townhome unit ductwork—revisions in red 


\subsubsection{Garage Exhaust Fan}

Because the townhomes have attached garages and use exhaust-only ventilation, provisions must be made to prevent contaminants in the garage from entering the home. This could be accomplished by equipping the garage with an exhaust fan vented directly outdoors with a minimum installed capacity of $70 \mathrm{CFM}$ at an installed cost of $\$ 120$ per fan. The fan can be wired for continuous operation or with automatic controls such as a motion detector that activates the fan whenever the garage is occupied and operates for at least 1 hour after the garage has been vacated.

Alternatively, the garage-to-house air barrier can be tested for integrity. The test requires the garage (with all openings closed) to maintain a pressure difference greater than 45 Pascals with the home while the home maintains a 50 Pascal pressure difference with respect to the outdoors (EPA 2013b).

The simplest and most reliable compliance option chosen for this analysis was a continuously operating exhaust fan. Although a verified garage-to-house air barrier would be preferable, it could not be guaranteed before construction; the additional cost to retrofit the fan postconstruction if the air barrier failed would be considerably higher than installing it at the start.

\subsubsection{Equipment Sizing Reduction}

The revised design peak heating and cooling loads as calculated with BEopt are about $25 \%$ lower than the original design for the townhome and about $10 \%$ lower for the apartment. Under ENERGY STAR Version 3, listed total cooling capacity must be $95 \%-115 \%$ of design total heat gain or next nominal size (generally in 0.5 -ton increments for single-speed equipment). For warm air heating systems, the output capacity must be $100 \%-140 \%$ of calculated system load (or next nominal size), unless a larger size is dictated by the cooling equipment selection (EPA 2013b). The ENERGY STAR-compliant townhome cooling equipment could be downsized from 3 to 2.5 tons; heating equipment could be reduced effectively to the next smaller nominal equipment size as well, a $32 \mathrm{kBtu} / \mathrm{h}$ unit, to meet ZERH requirements (Table 13).

Table 13. Space-Conditioning Equipment Sizing Reduction

\begin{tabular}{c|c|c|c}
\hline & & $\begin{array}{c}\text { Heating } \\
\text { (kBtu/h) }\end{array}$ & $\begin{array}{c}\text { Cooling } \\
\text { (tons) }\end{array}$ \\
\hline \multirow{4}{*}{ Apartment } & Original load & 22.3 & 1.7 \\
& Original specified capacity & 27.1 & 2 \\
& ZERH load & 21.7 & 1.6 \\
& ZERH specified capacity & 27.1 & 2 \\
& Capacity reduction & 0 & 0 \\
& Original load & 36.2 & 2.69 \\
& Original specified capacity (next closest size) & 57.4 & 3 \\
& ZERH load & 28.5 & 2.01 \\
& ZERH specified capacity & 32.4 & 2.5 \\
& Capacity reduction & 25 & 0.5 \\
\hline
\end{tabular}




\subsubsection{Summary of Design Changes}

The following table (Table 14) summarizes the design changes needed to comply with ZERH:

Table 14. Design Changes

\begin{tabular}{|c|c|}
\hline Item & Change \\
\hline UA-Exterior Walls & $\begin{array}{l}\text { Change from R-3 exterior rigid insulation to R-6 exterior rigid } \\
\text { insulation. This change drives reductions in heating and cooling } \\
\text { equipment sizing. }\end{array}$ \\
\hline $\begin{array}{l}\text { Domestic Water } \\
\text { Heating Distribution } \\
\text { Efficiency }\end{array}$ & $\begin{array}{l}\text { Move water heaters to central location-increase vent length; } \\
\text { decrease pipe length }\end{array}$ \\
\hline Duct Protection & $\begin{array}{l}\text { Cover duct openings during construction and vacuum out ducts } \\
\text { thoroughly before installing registers, grilles, and diffusers }\end{array}$ \\
\hline $\begin{array}{l}\text { Air Distribution } \\
\text { System Design }\end{array}$ & $\begin{array}{l}\text { Bring ducts into conditioned space by installing soffit in townhome } \\
\text { second floor and installing a trunk duct down the center of the unit } \\
\text { with short branch ducts to each room. Registers would be located in } \\
\text { the interior walls rather than the sidewall. } \\
\text { Change from MERV } 6 \text { to MERV } 8 \text { filters for all air handling units }\end{array}$ \\
\hline Attached Garages & Install 70 CFM fan vented to outdoors \\
\hline Pest Control & $\begin{array}{l}\text { Add rodent- and corrosion-proof screens to exhaust fans and } \\
\text { combustion vent }\end{array}$ \\
\hline
\end{tabular}




\section{Modeling}

BEopt version 2.2.0.2 was used to create energy models of the original design, the ZERHcompliant, and a minimum ENERGY STAR-compliant version of the apartment and townhome to estimate source energy savings and evaluate annualized energy-related costs. Costs to upgrade from the original design to ZERH were obtained from subcontractors and estimates by the developer (Table 15). The BEopt cost database was used for costs of ENERGY STAR Version 3 minimum specifications (Table 16). The costs in Table 16 would be added to those in Table 15 if using ENERGY STAR Version 3 minimum as the baseline.

Table 15. Incremental Costs-Original Design to ZERH

\begin{tabular}{|c|c|c|}
\hline Item & Design Change & Incremental Cost/Savings \\
\hline $\begin{array}{l}\text { Exterior } \\
\text { Walls }\end{array}$ & $\begin{array}{c}1 \text {-in. R-3 to } 1.5 \text {-in. R-6 insulated } \\
\text { sheathing }\end{array}$ & $\begin{array}{l}\$ 1.04 / \mathrm{ft}^{2} \text { exterior wall area, resulting in a } \\
\$ 894 \text { cost increase for the apartment and } \\
\$ 1,284 \text { increase for the townhome. }\end{array}$ \\
\hline $\begin{array}{l}\text { Domestic } \\
\text { Water } \\
\text { Heating }\end{array}$ & $\begin{array}{l}\text { Relocated water heater-polyvinyl } \\
\text { chloride pipe extension for both } \\
\text { intake and exhaust; reduced water } \\
\text { pipe and heat loop pipe lengths }\end{array}$ & $\begin{array}{l}\$ 4 / 1 \text { of length from outside wall plus } \$ 50 \\
\text { labor per apartment. Saving from reduced } \\
\text { heat loop and DHW pipe: } \$ 0.21 / 1 \text { f of } 1 / 2 \text { in.; } \\
\$ 0.38 / \text { lf of } .075 \text { in.; } \$ 1.10 / 1 \text { of } 1 \text { in. Net } \\
\text { cost of } \$ 68 / \text { apartment and } \$ 110 / \text { townhome. }\end{array}$ \\
\hline $\begin{array}{c}\text { Duct } \\
\text { Protection }\end{array}$ & $\begin{array}{l}\text { Cover duct openings during } \\
\text { construction and vacuum out ducts } \\
\text { on completion }\end{array}$ & 2 hours total per unit at $\$ 22 / \mathrm{h}=\$ 44 /$ unit \\
\hline \multirow[t]{2}{*}{$\begin{array}{l}\text { Air } \\
\text { Distribution } \\
\text { System } \\
\text { Design }\end{array}$} & \multirow{2}{*}{$\begin{array}{l}\text { Soffit in the townhome top floor. } \\
\text { Trunk down center of apartment } \\
\text { with registers in center rather than } \\
\text { near sidewall } \\
\text { MERV } 6 \text { to MERV } 8 \text { filters for all } \\
\text { air handling units }\end{array}$} & $\begin{array}{l}\$ 100 / \text { townhome for additional framing; } \\
\$ 82.50 \text { savings for reduced ductwork } \\
\text { (\$2.20/1f for } 8 \text {-in. flex duct and } \$ 11 / 1 \text { f for } \\
12 \text {-in. } \times 12 \text {-in. fiberboard trunk duct); } \\
\text { resulting in a negligible net increase of } \\
\$ 17.50 \text {. }\end{array}$ \\
\hline & & $\$ 3$ additional per filter \\
\hline $\begin{array}{l}\text { Attached } \\
\text { Garages }\end{array}$ & 70 CFM fan and labor & $\$ 120$ for townhomes only \\
\hline $\begin{array}{c}\text { Pest } \\
\text { Control }\end{array}$ & $\begin{array}{l}\text { Rodent- and corrosion-proof } \\
\text { screens to exhaust fans and } \\
\text { combustion vent }\end{array}$ & $\begin{array}{c}\text { \$5/vent or \$20/apartment and } \\
\$ 25 / \text { townhome }\end{array}$ \\
\hline $\begin{array}{l}\text { Equipment } \\
\text { Size }\end{array}$ & $\begin{array}{l}\text { Townhome air conditioner and } \\
\text { heating coil downsize }\end{array}$ & $\begin{array}{c}\$ 100 \text { reduced cost for } 3 \text { to } 2.5 \text { ton air } \\
\text { conditioner and } \$ 200 \text { reduced cost for } 57.4 \\
\text { to } 32.4 \mathrm{kBtu} / \mathrm{h}\end{array}$ \\
\hline
\end{tabular}


Table 16. Additional Incremental Costs-ENERGY STAR Version 3 Baseline to ZERH

\begin{tabular}{c|c|c|c}
\hline Item & $\begin{array}{c}\text { ENERGY STAR } \\
\text { Version 3 } \\
\text { Minimum }\end{array}$ & ZERH & Incremental Costs \\
\hline Cavity Insulation & R-13 & R-15 & \$0.06/ $\mathrm{ft}^{2}$ exterior wall \\
Cooling Equipment & SEER 13 & $\begin{array}{c}\text { SEER 14.5 } \\
\text { (NYSERDA } \\
\text { requirement) }\end{array}$ & \$123/unit \\
$\begin{array}{c}\text { Space- and Water- } \\
\text { Heating Equipment }\end{array}$ & $\begin{array}{c}0.92 \text { EF tankless } \\
\text { water heater }\end{array}$ & $\begin{array}{c}0.96 \text { EF tankless } \\
\text { water heater }\end{array}$ & $\$ 67 /$ unit \\
\hline
\end{tabular}

Projected annual source energy consumption was reduced by about $2 \%$ for the apartment and $8 \%$ for the townhome (Figure 6 and Figure 7) when comparing the original to the ZERH designs. This reduction is small because the original design was already superior to minimum ENERGY STAR requirements - by $8 \%$ for both the apartment and townhome-primarily due to the minimum space heating equipment efficiency requirement of 90 AFUE imposed by NYSERDA. Many of the additional ZERH design changes related to indoor air quality (and one for pest protection). The reduction in energy use from the as-built design was due to the upgrade in exterior rigid insulation from R-3 to R-6, relocation of the DHW heater and relocating ducting into conditioned space in the townhome. Adding garage ventilation in the townhome increased energy use there. The DHW distribution energy savings was factored into BEopt by adjusting the hot water fixture use fraction from 1.0 to 0.95 for the apartment and to 0.97 for the townhome.

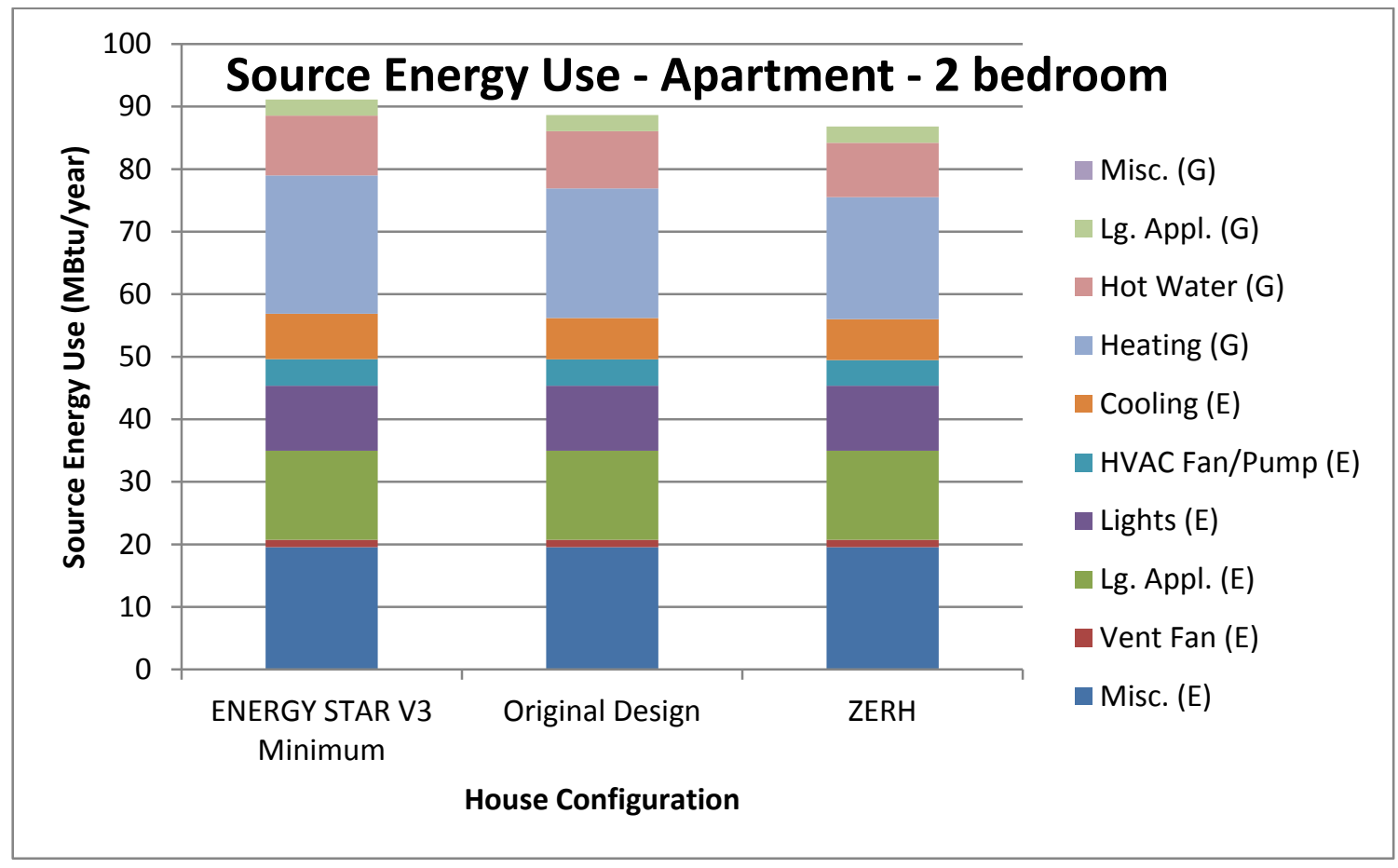

Figure 6. Apartment source energy use from BEopt 


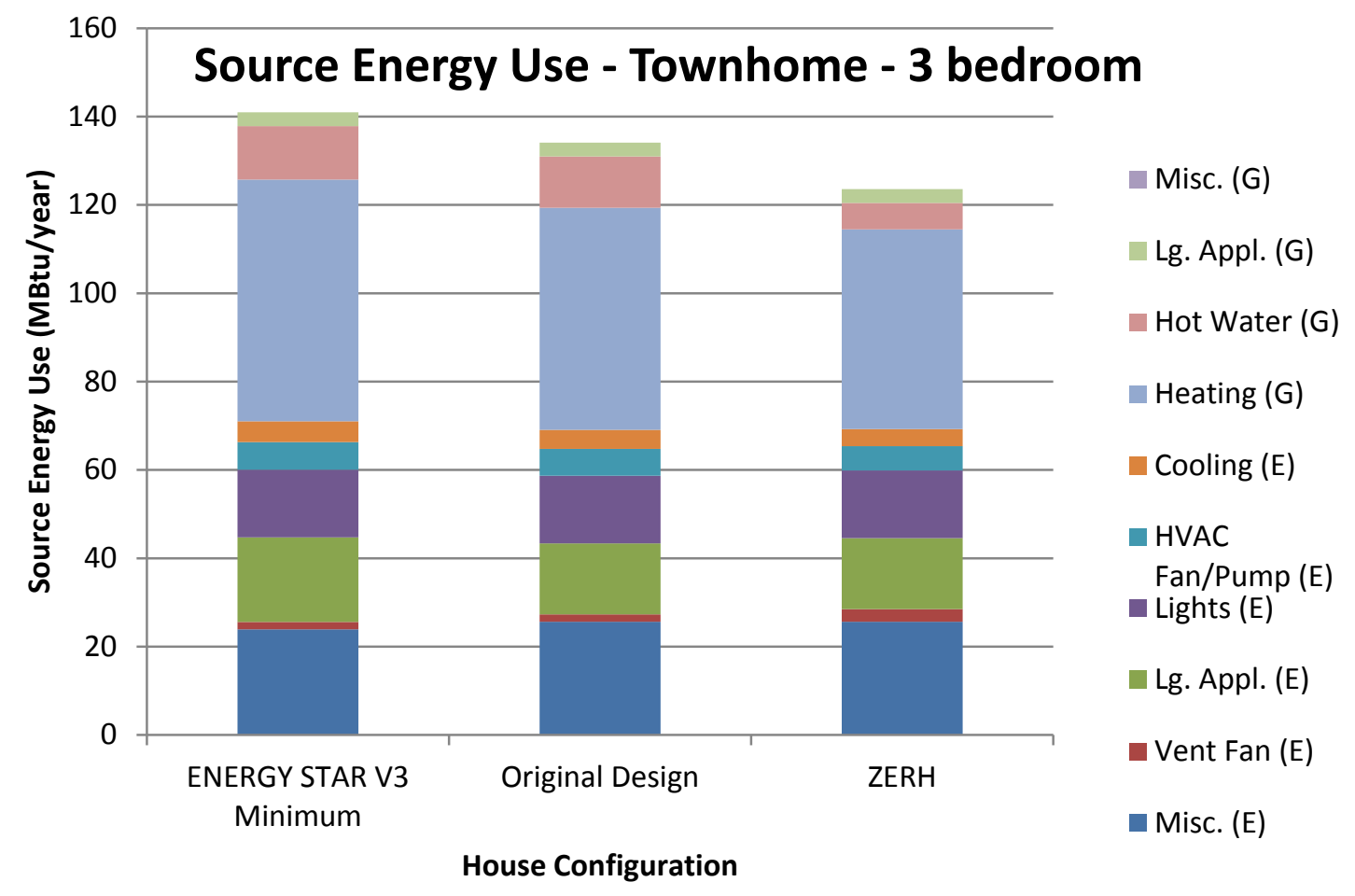

Figure 7. Townhome source energy use from BEopt

In Figure 8 and Figure 9, the source energy savings compared to a baseline home (2009 IECC) and the annualized energy-related costs of three design specifications are presented: ENERGY STAR Version 3 minimum, the original design, and ZERH. The annualized energy-related costs account for the utility bill savings and the incremental construction costs associated with the upgrades. All the additional costs, including the non-energy-related upgrade costs required by ZERH were factored into this analysis. For the apartment, the BEopt annualized energy-related costs for the ZERH design are lower than the ENERGY STAR minimum and original design by $\$ 2$ and $\$ 12$, respectively. For the townhome the BEopt annualized energy-related costs for the ZERH design are lower than the ENERGY STAR minimum and original design by $\$ 79$ and $\$ 134$, respectively. For the apartment, adjusted source energy savings increased by $3.2 \%$ and $1.4 \%$ for the ZERH compared to the ENERGY STAR minimum and original design, respectively. For the townhome, adjusted source energy savings increased by $9.5 \%$ and $5.8 \%$ for the ZERH compared to the ENERGY STAR minimum and original design, respectively. Utility rates used are shown in Table 17. 


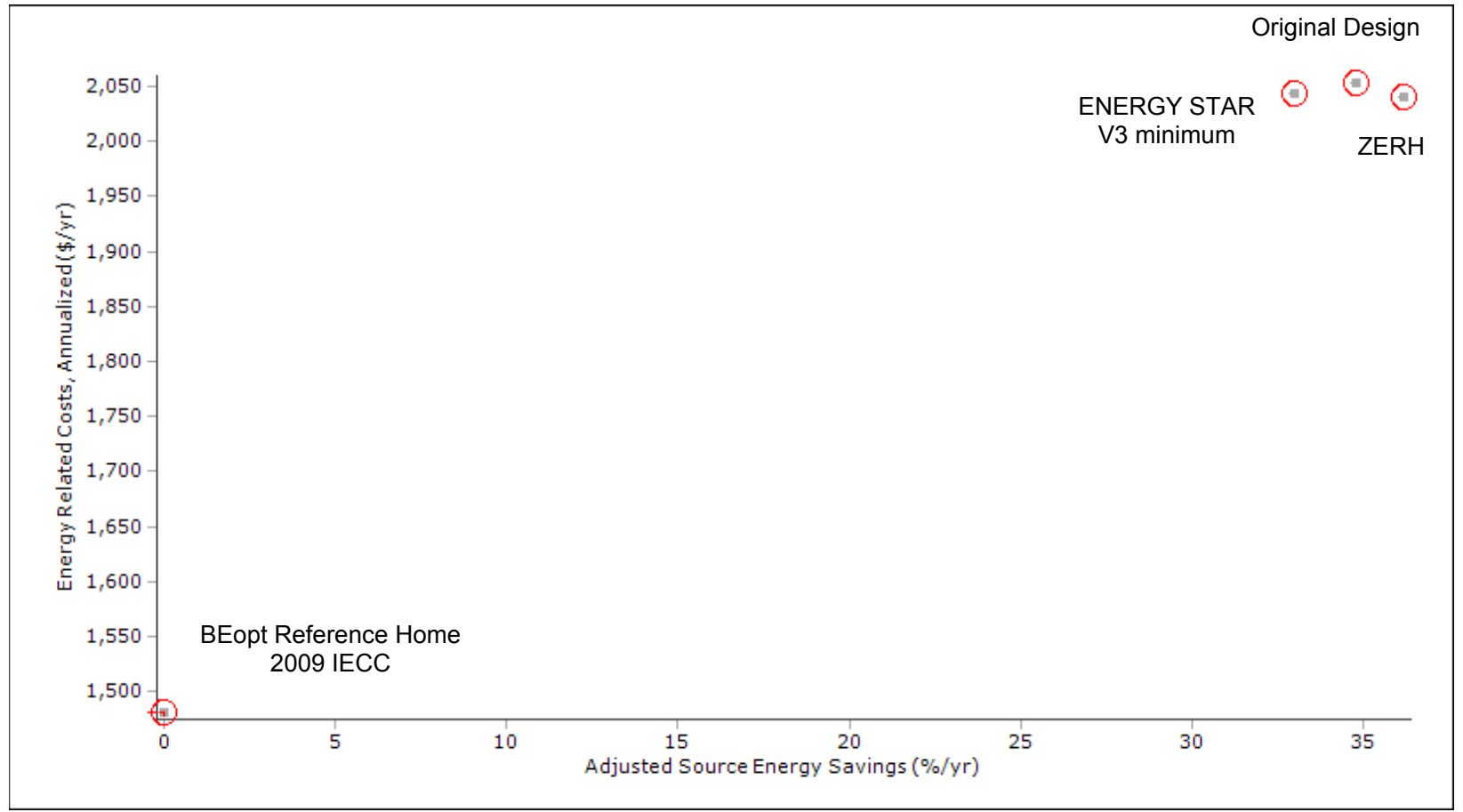

Figure 8. Apartment (single unit B4) annualized energy-related costs from BEopt

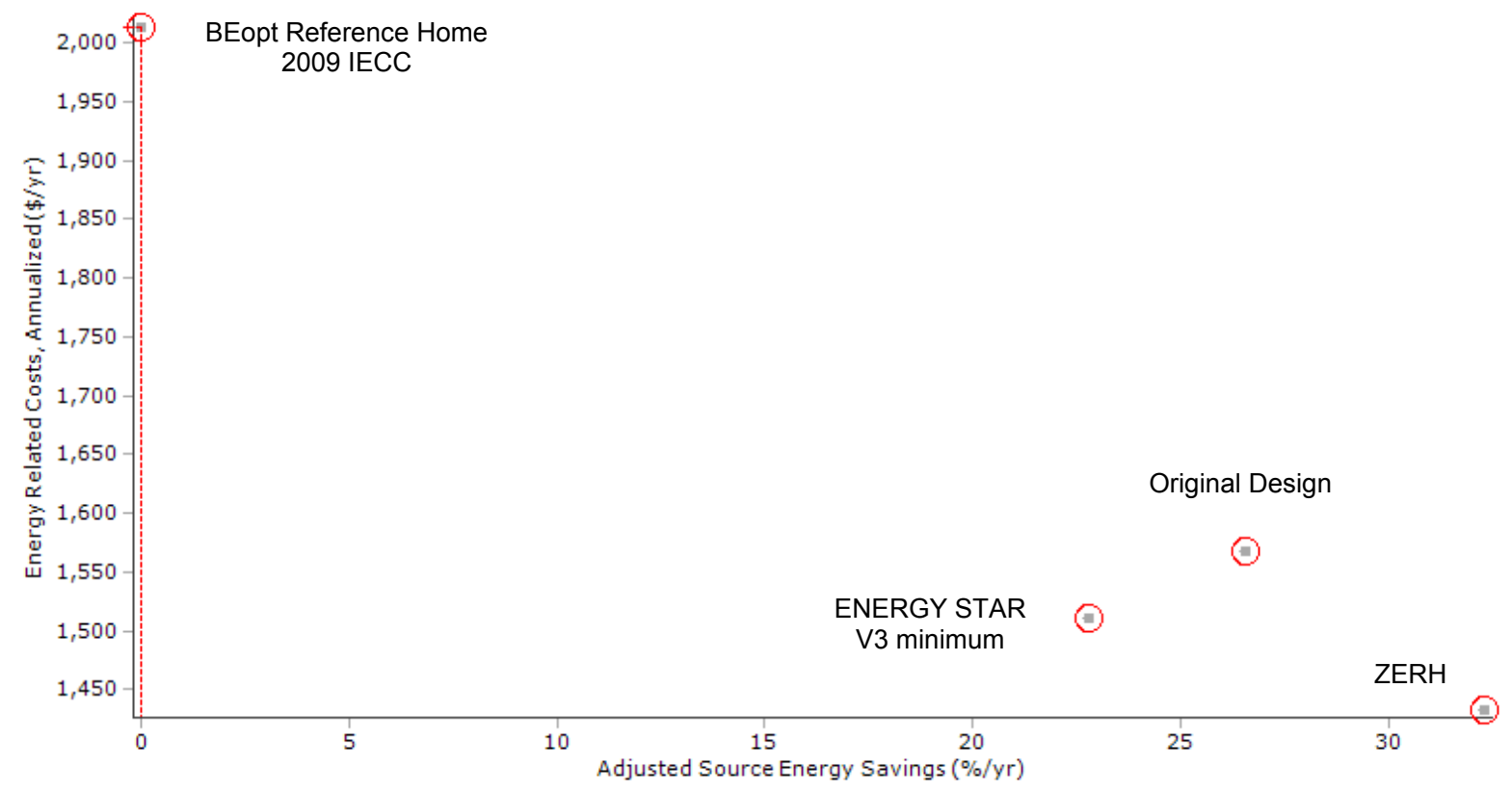

Figure 9. Townhome (single unit TC3) annualized energy-related costs from BEopt 


\section{Table 17. Utility Rates}

\begin{tabular}{c|c}
\hline Utility & Rate \\
\hline Electricity & $\$ 8 /$ month $+\$ 0.13 / \mathrm{kWh}$ \\
Natural gas & $\$ 8 /$ month $+\$ 1.10 /$ therm \\
\hline
\end{tabular}

The impact on the renters' utility bills is shown in Table 18. In this case the savings accrue to the renters, not to the developer that incurred the additional costs. The projected HERS indices for the units are shown in Table 19.

Table 18. Projected Annual Utility Bill Savings for the Original and ZERH Designs

\begin{tabular}{c|c|c}
\hline & $\begin{array}{c}\text { Utility Bill Savings for } \\
\text { Original Design Compared to } \\
\text { ENERGY STAR Version 3 } \\
\text { Minimum }\end{array}$ & $\begin{array}{c}\text { Utility Bill Savings for ZERH } \\
\text { Compared to ENERGY STAR } \\
\text { Version 3 Minimum }\end{array}$ \\
\hline $\begin{array}{c}\text { Apartment } \\
\text { Townhome }\end{array}$ & $\$ 24$ & $\$ 41$ \\
\hline
\end{tabular}

Table 19. HERS Indices for Original and ZERH Designs

\begin{tabular}{c|c|c|c}
\hline & $\begin{array}{c}\text { ENERGY STAR Version 3 } \\
\text { Minimum }\end{array}$ & $\begin{array}{c}\text { Original } \\
\text { Design }\end{array}$ & ZERH \\
\hline Apartment & 71 & 58 & 58 \\
Townhome & 71 & 56 & 52 \\
\hline
\end{tabular}




\section{Results and Discussion}

\subsection{Cost-Effectiveness}

One purpose of this analysis was to document the costs necessary to step up from the original design, which was compliant with ENERGY STAR Version 3, to ZERH for multifamily builder. Cost determines to a large extent the feasibility of implementing ZERH for this market segment. The overall costs to upgrade from the original design to ZERH are shown in Table 20. This development was only 68 units because it was an addition to a larger development. Therefore, the total project incremental costs were modest. Typical new developments range from 200 to 400 units, so total additional costs could be hundreds of thousands of dollars in those cases. The incremental costs to upgrade from a hypothetical ENERGY STAR Version 3 minimum design to ZERH are shown in Table 21.

Table 20. Total Incremental Costs from Original Design to ZERH

\begin{tabular}{c|c|c|c}
\hline & $\begin{array}{c}\text { Cost per Square } \\
\text { Foot Floor Area }\end{array}$ & $\begin{array}{c}\text { Cost for } \\
\text { Sample Unit }\end{array}$ & $\begin{array}{c}\text { Cost per Building } \\
\text { Sa }\end{array}$ \\
\hline Apartment (B4) & $\$ 0.77$ & $\$ 1,029$ & $\$ 17,506(\mathrm{x} 2$ buildings) \\
Townhome (TC3) & $\$ 0.72$ & $\$ 1,304$ & $\$ 6,723$ \\
Total project & & & $\$ 41,735$ \\
\hline
\end{tabular}

${ }^{a}$ Extrapolates exterior insulation costs per foot to entire building envelope; assumes all other incremental costs are equal for all apartments.

Table 21. Total Incremental Costs from ENERGY STAR Version 3 Minimum Design to ZERH

\begin{tabular}{c|c|c|c}
\hline & $\begin{array}{c}\text { Cost per Square } \\
\text { Foot Floor Area }\end{array}$ & $\begin{array}{c}\text { Cost for } \\
\text { Sample Unit }\end{array}$ & Cost per Building $^{\mathrm{a}}$ \\
\hline Apartment (B4) & $\$ 1.08$ & $\$ 1,444$ & $\begin{array}{c}\$ 28,484(\mathrm{x} 2 \\
\text { buildings) }\end{array}$ \\
$\begin{array}{c}\text { Townhome (TC3) } \\
\text { Total project }\end{array}$ & $\$ 1.28$ & $\$ 2,319$ & $\begin{array}{c}\$ 14,630 \\
\$ 71,598\end{array}$ \\
\hline
\end{tabular}

${ }^{a}$ Extrapolates exterior insulation costs per foot to entire building envelope; assumes all other incremental costs are equal for all apartments.

The residents pay for all utilities in these rental apartments, so the savings would accrue to the residents; the construction costs would be borne by the developer. The developer would be motivated to make these improvements only if they increased marketability, raised rents, increased occupant satisfaction, or reduced maintenance costs. These factors are discussed in Section 5.2.

\subsection{Impacts and Trade-Offs}

Of the seven upgrades required to comply with the ZERH requirements, four have energy impacts (one of which increases energy use), three relate to indoor environmental quality, and one to pests. The DHW distribution efficiency requirement reduces energy waste but also improves performance in the form of less wait time for hot water and reduced water waste. A discussion of other impacts of the changes is provided in Table 22. 


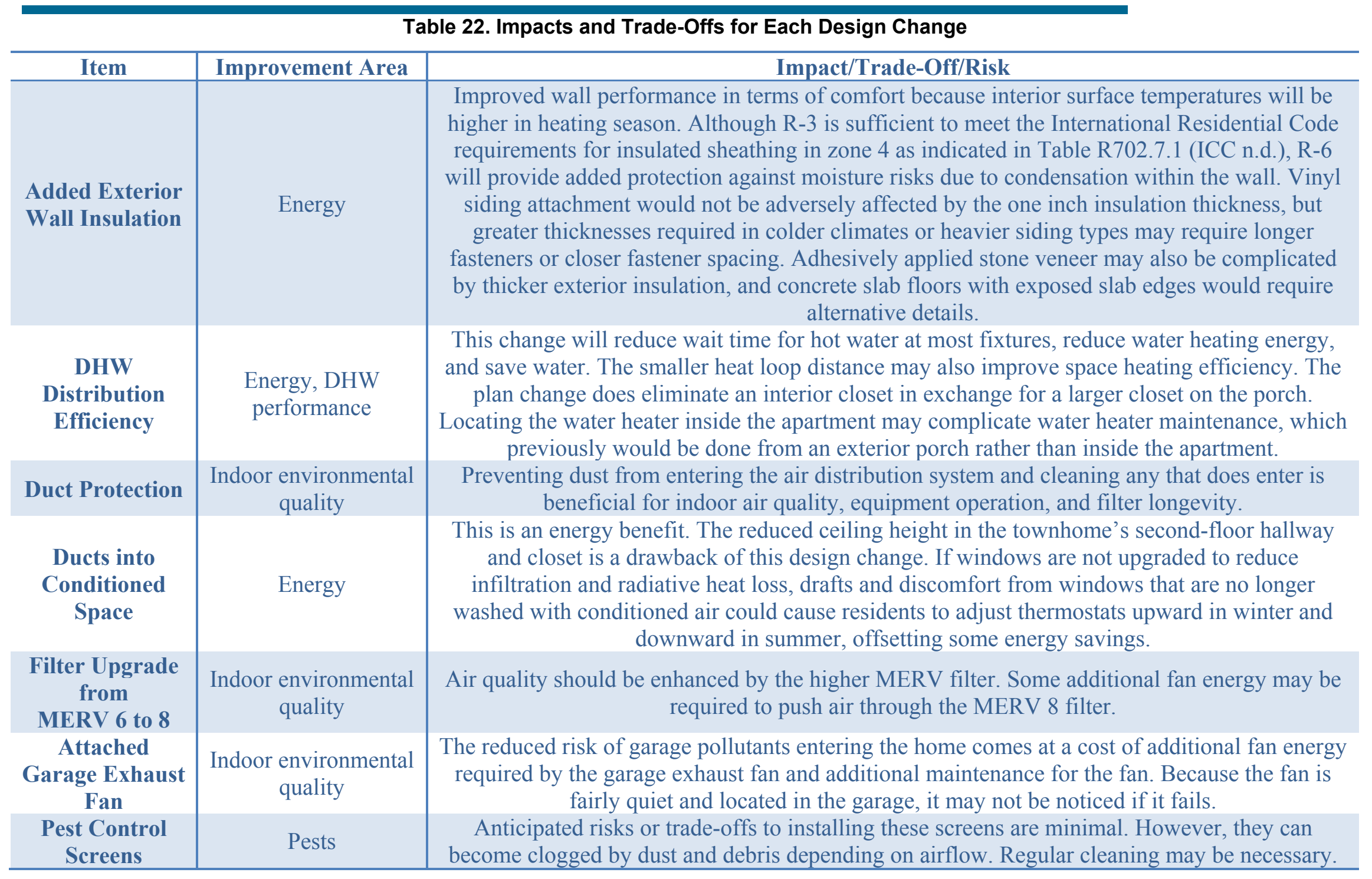




\section{Conclusions}

Four research questions were addressed by this analysis:

1. What set of measures can successfully result in meeting DOE ZERH specifications for a market-rate multifamily project in climate zone 4 ?

The primary energy measures that achieve compliance with ZERH exceed ENERGY STAR Version 3 only slightly. The units analyzed complied with R-10 slab edge insulation, R-30 floor insulation (or R-15 over podium slab), R-15 wall cavity insulation, R-6 insulating sheathing, U0.32 windows, R-30 and R-38 ceilings, 96\% efficiency water and space heating, and 13 SEER cooling.

2. What changes are required to upgrade a multifamily development from ENERGY STAR to ZERH? What design and construction approaches can help streamline the move to ZERH production?

For the units in the sample project analyzed, relatively few items (seven) would need to be modified from the original design. The modifications are:

- Increase the exterior rigid insulation thickness from $1 / 2 \mathrm{in}$. to $1 \mathrm{in}$.

- Relocate the water heaters.

- Bring the ducts into a dropped soffit in townhome units.

- Upgrade to MERV 8 filters.

- Add rodent screens to vents.

- Protect and clean ducts.

- Install an exhaust fan in the garage of each townhome unit.

All these design upgrades could have been incorporated relatively easily any time before construction; however, the DHW distribution and duct location changes would optimally be made during the design phase. The design changes (dropped soffit for townhome ducts and using closet space for water heaters) would be a major drawback for some developers - alternatives that have a lower design impact may be necessary.

If the development was starting at a baseline of ENERGY STAR Version 3 minimum, the following additional upgrades would be required:

- Increase cavity insulation from R-13 to R-15.

- Increase space and DHW heating tankless unit efficiency from 0.92 EF to 0.96 EF.

- For NYSERDA incentives, increase the air-conditioner condenser efficiency from SEER 13 to SEER 14.5.

3. What are the resulting costs to upgrade a multifamily development from ENERGY STAR to ZERH? Can any construction cost savings be captured as a result of reduced equipment needs? 
The net costs to upgrade to ZERH are approximately $\$ 1,029$ and $\$ 1,304$ for a typical apartment and townhome, respectively. Extrapolating this to all three buildings would result in an approximately $\$ 42,000$ increase in construction cost for all 68 units, or $\$ 0.57 / \mathrm{ft}^{2}$. The full added costs were higher but savings from reduced piping and ductwork and equipment downsizing offset some of those costs.

If the development was starting at a baseline of ENERGY STAR minimum, the net costs to upgrade to ZERH would be approximately \$1,444 and \$2,319 for a typical apartment and townhome, respectively. Extrapolating this to all 68 units would result in an overall upgrade cost of approximately $\$ 79,000$ or about $\$ 1.09 / \mathrm{ft}^{2}$. Again, the fully added costs were higher but savings from equipment downsizing and reduced domestic hot water piping and ductwork offset these costs.

4. What are the energy impacts of upgrading a multifamily development from ENERGY STAR to ZERH? Is it cost-effective as calculated via BEopt modeling?

Upgrading from the original ENERGY STAR design to ZERH resulted in a projected 2\%-8\% reduction of source energy consumption, or 1.9-10.4 MBtu/year. This number is modest, in part because the original design was already $8 \%$ better than the ENERGY STAR minimum requirements in terms of source energy consumption. Annualized energy-related costs of the ZERH design were approximately $\$ 12$ lower for the apartment and approximately $\$ 134$ lower for the townhome compared to the original design. 


\section{References}

Burdick, A. 2013. Strategy Guideline: Compact Air Distribution Systems (Subcontractor Report). Golden, CO: National Renewable Energy Laboratory, NREL/SR-550057349. www.nrel.gov/docs/fy13osti/57349.pdf.

Dentz, J.L., E. Ansanelli, K. Varshney, and H.I. Henderson. 2015. Energy-Efficient Controls for Multifamily Domestic Hot Water Systems Final Report. Albany: New York State Energy Research and Development Authority.

DOE. 2012. DOE Challenge Home Label Methodology. U.S. Department of Energy: www1.eere.energy.gov/buildings/residential/pdfs/ch_label_methodology_1012.pdf.

DOE. 2014a. "The Hub of Innovation for American Housing” U.S. Department of Energy: http://energy.gov/sites/prod/files/2014/05/f15/Building_America_Overview_Werling_042214_a nd_042314.pdf

DOE. 2014b. DOE Zero Energy Ready Home National Program Requirements (Rev. 4). Washington, D.C.: U.S. Department of Energy, accessed February 12, 2015: www.energy.gov/sites/prod/files/2014/04/f15/doe_zero_energy ready home_requirement s rev04.pdf.

DOE. 2015a. "DOE Challenge Home Consolidated Renewable Energy Ready Home Checklist." U.S. Department of Energy: http://energy.gov/sites/prod/files/2013/11/f5/rerh_ch_checklists_623-13.pdf.

DOE. 2015b. Guidelines for Participating in the DOE Zero Energy Ready Home. Washington, D.C.: U.S. Department of Energy, accessed February 12, 2015: http://energy.gov/eere/buildings/guidelines-participating-doe-zero-energy-ready-home.

EPA. 2013a. Indoor airPLUS Construction Specifications. Washington, D.C.: U.S. Environmental Protection Agency, accessed February 11, 2015: www.epa.gov/indoorairplus/pdfs/construction_specifications.pdf.

EPA. 2013b. Inspection Checklists. Washington, D.C.: U.S. Environmental Protection Agency, accessed February 11, 2015: www.energystar.gov/ia/partners/bldrs_lenders_raters/downloads/Inspection_Checklists.pd f.

EPA. 2014. WaterSense New Home Specification. Washington, D.C.: U.S. Environmental Protection Agency, accessed August 17, 2015: http://www.epa.gov/WaterSense/docs/home finalspec508.pdf .

Hendron, B., J. Burch, and G. Barker. 2010. "Tool for Generating Realistic Residential Hot Water Event Schedules.” Presented at SimBuild 2010, New York, NY,August 15-19, 2010. Golden, CO: National Renewable Energy Laboratory, CP-550047685. www.nrel.gov/docs/fy10osti/47685.pdf. 
ICC. 2007. 2010 Plumbing Code of New York State. Retrieved February 13, 2015, from International Code Council Public Codes:

http://publicecodes.cyberregs.com/st/ny/st/b900v10/st_ny_st_b900v10_5_sec002.htm

ICC. 2012. Section R402 Building Thermal Envelope. Retrieved June 11, 2015, from International Energy Conservation Code:

http://publicecodes.cyberregs.com/icod/iecc/2012/icod_iecc_2012_re4_sec002.htm

ICC. (n.d.). International Residential Code for One- and Two-Family Dwellings. Washtington, D.C.: International Code Council, accessed February 12,

2015: http://publicecodes.cyberregs.com/icod/irc/2012/icod_irc_2012 7 sec002_par025.htm.

Nebbia, J. 2014. Personal communication, J. Dentz, Interviewer.

NREL. 2012. "BEopt v1.2 Help Menu: Annualized Energy Related Costs.” Golden, CO:

National Renewable Energy Laboratory.

NYSERDA. 2014. PON 2309 - Low-rise Residential New Construction. Albany, NY: New York State Energy Research and Development Authority, accessed June 12, 2015: www.nyserda.ny.gov/Funding-Opportunities/Current-Funding-Opportunities/PON-2309Low-Rise-Residential-New-Construction-Program.

TLV, Inc. 2015. "Calculator: Water Flow Rate through Piping.” Noguchi, Japan: TLV A Steam Specialist Company, accessed August 17, 2015: www.tlv.com/global/TI/calculator/water-flowrate-through-piping.html

U.S. Census Bureau. n.d. New Privately Owned Housing Units Authorized by Building Permits in Permit-Issuing Places. Washington, D.C.: U.S. Census Bureau, accessed December 17, 2014: www.census.gov/construction/nrc/historical_data/.

University of British Columbia. n.d. Mathematics 256. Vancouver, BC: University of British Columbia, accessed March 9, 2015 www.math.ubc.ca/ cass/courses/m256-7b/heat.pdf. 


\section{Appendix}

\section{Domestic Hot Water Distribution Waste Calculation}

Assumptions:

- Ignore draws of shorter duration than water flow time from the water heater to the highest-use fixture in the zone.

- Ignore draws less than 10 min after previous draw from the same fixture or fixture in same zone (based on pipe heat loss calculations from $125^{\circ} \mathrm{F}$ to $105^{\circ} \mathrm{F}$ in 0.75 -in. pipe).

- Base waste on the counted number of qualifying events per fixture.

- Climate location: New York, LaGuardia.

- Tank temperature $125^{\circ} \mathrm{F}$ (DHW draw generator default value).

- Draw temperature $110^{\circ} \mathrm{F}$ (DHW draw generator default value).

- Wasted water is equivalent to the pipe volume from the water heater to the highest-use fixture in the zone.

- Wasted energy is equivalent to the Btu embedded in the wasted water volume, assuming temperature rise from mains water temperature $\left(56^{\circ} \mathrm{F}\right)$ to $125^{\circ} \mathrm{F}$ divided by water heater efficiency $(96 \%)$.

- Estimations of pipe volume from water heater to highest use fixture for purposes of estimating DHW waste assumes .075-in. diameter throughout.

\section{Pipe Heat Loss Calculation}

Steady-state heat loss equation (University of British Columbia n.d.): $\theta_{\text {target }}=\theta_{\text {environmental }}+$ $\left(\theta_{0}-\theta_{\text {environmental }}\right) * \mathrm{e}^{-\mathrm{kt}}$

Where:

$\theta_{\text {environmental is wall cavity temperature }\left(70^{\circ} \mathrm{F}\right)}$

$\theta_{0}$ is original water temperature $\left(125^{\circ} \mathrm{F}\right)$

$\theta_{\text {target }}$ is target water temperature $\left(105^{\circ} \mathrm{F}\right)$

After inputting known variables and solving for t, the time for water to cool from $125^{\circ} \mathrm{F}$ to $105^{\circ} \mathrm{F}$ is approximately $10 \mathrm{~min}$. 
Table 23. Inputs and Results-DHW Distribution Waste-Apartment

\begin{tabular}{|c|c|c|c|c|}
\hline Zone & 1 & 2 & 3 & 4 \\
\hline Fixtures in zone & $\begin{array}{l}\text { Kitchen } \\
\text { sink } \\
\text { dishwasher }\end{array}$ & $\begin{array}{l}\text { M bathtub } \\
\text { M bath } \\
\text { lavatories } \\
\text { M bath } \\
\text { shower }\end{array}$ & $\begin{array}{c}\text { Bath } 2 \\
\text { bathtub } \\
\text { bath } 2 \text { shower } \\
\text { bath } 2 \\
\text { lavatory } \\
\text { washing } \\
\text { machine }\end{array}$ & $\begin{array}{l}\text { Wet } \\
\text { bar }\end{array}$ \\
\hline $\begin{array}{c}\text { Limit (min) based on heat loss calc .075- } \\
\text { in. uninsulated PEX } 125 \text { tank temp to } \\
105 \text { useful temp }\end{array}$ & 10 & 10 & 10 & 10 \\
\hline $\begin{array}{l}\text { Duration minimum (seconds). Draws } \\
\text { shorter than this will not yield hot water } \\
\text { so hot water is presumably not needed } \\
\text { (assume ZERH location has same } \\
\text { duration limit as original location) }\end{array}$ & 15.6 & 30.8 & 24.5 & 22.2 \\
\hline Counted draws & 2,773 & 788 & 447 & 535 \\
\hline Average counted draws per day & 7.60 & 2.16 & 1.22 & 1.47 \\
\hline $\begin{array}{l}\text { Pipe length to highest-use fixture-- } \\
\text { original case (kitchen sink) (ft) }\end{array}$ & 20.6 & 40.7 & 32.4 & 29.3 \\
\hline $\begin{array}{l}\text { Pipe length to highest-use fixture- } \\
\text { ZERH case (kitchen sink) (ft) }\end{array}$ & 16.5 & 24.3 & 15.8 & 12.5 \\
\hline $\begin{array}{c}\text { Pipe volume to highest-use fixture-- } \\
\text { original case (kitchen sink) (gal); } \\
\text { assumes } 0.75 \text {-in. pipe }\end{array}$ & 0.53 & 1.04 & 0.83 & 0.75 \\
\hline $\begin{array}{l}\text { Pipe volume to highest-use fixture- } \\
\text { ZERH case (kitchen sink) (gal); assumes } \\
\text { 0.75-in. pipe }\end{array}$ & 0.42 & 0.62 & 0.4 & 0.32 \\
\hline Total DHW waste—hot only (gal) & 896 & 342 & 280 & 448 \\
\hline Total DHW use-hot only (gal) & 5,381 & 7,764 & 515 & 2,792 \\
\hline$\%$ waste DHW & $16.6 \%$ & $4.4 \%$ & $54.3 \%$ & $16 \%$ \\
\hline $\begin{array}{l}\text { Total water use from hot water taps } \\
\text { (gal) (includes cold water used to } \\
\text { temper DHW at tap) }\end{array}$ & 6,673 & 9,849 & 681 & 3,064 \\
\hline $\begin{array}{c}\text { Total water waste (gal) from hot water } \\
\text { taps }\end{array}$ & 1,169 & 820 & 370 & 401 \\
\hline $\begin{array}{l}\text { Flow rate highest-use fixture (gal/min } \\
\text { based on federal standards) } \\
\text { (EPA 2014) }\end{array}$ & 2.2 & 2.2 & 2.2 & 2.2 \\
\hline Pipe diameter to highest-use fixture (in.) & 0.75 & 0.75 & 0.75 & 0.75 \\
\hline $\begin{array}{l}\text { Flow speed highest-use fixture (ft/s) } \\
\text { (TLV, Inc. 2015) }\end{array}$ & 1.32 & 1.32 & 1.32 & 1.32 \\
\hline
\end{tabular}


Table 24. Inputs and Results-DHW Distribution Waste-Townhome

\begin{tabular}{|c|c|c|c|c|}
\hline & Original & \multicolumn{3}{|c|}{ ZERH } \\
\hline Fixtures in zone & All & 1 & 2 & 3 \\
\hline $\begin{array}{c}\text { Limit (min) based on heat loss } \\
\text { calculation .075-in. uninsulated PEX } \\
125 \text { tank temperature to } 105 \text { useful } \\
\text { temperature }\end{array}$ & All & $\begin{array}{l}\text { Kitchen sink } \\
\text { Dishwasher } \\
\text { M bathtub } \\
\text { M bath sink } \\
\text { M bath shower }\end{array}$ & $\begin{array}{l}\text { Powder } \\
\text { room } \\
\text { sink } \\
\text { clothes } \\
\text { washer }\end{array}$ & $\begin{array}{c}\text { Bath } 2 \\
\text { bathtub } \\
\text { Bath } 2 \\
\text { shower } \\
\text { Bath } 2 \\
\text { Sink }\end{array}$ \\
\hline $\begin{array}{l}\text { Duration minimum (seconds). Shorter } \\
\text { draws will not yield hot water so hot } \\
\text { water is presumably not needed } \\
\text { (assume ZERH location has same } \\
\text { duration limit as original location) }\end{array}$ & 10 & 10 & 10 & 10 \\
\hline Counted draws & 43.3 & 43.3 & 43.3 & 4303 \\
\hline Average counted draws per day & 2,187 & 2,123 & 294 & 362 \\
\hline $\begin{array}{l}\text { Pipe length to highest-use fixture- } \\
\text { original case (kitchen sink) (ft) }\end{array}$ & 5.99 & 5.82 & 0.81 & 0.99 \\
\hline $\begin{array}{l}\text { Pipe length to highest-use fixture- } \\
\text { ZERH case (kitchen sink) (ft) }\end{array}$ & 57.2 & $\mathrm{~N} / \mathrm{A}$ & N/A & N/A \\
\hline $\begin{array}{l}\text { Pipe volume to highest-use fixture- } \\
\text { original case (kitchen sink) (gal); } \\
\text { assumes } 0.75 \text {-in. pipe }\end{array}$ & $\mathrm{N} / \mathrm{A}$ & 18.9 & 11.1 & 17.5 \\
\hline $\begin{array}{l}\text { Pipe volume to highest-use fixture- } \\
\text { ZERH case (kitchen sink) (gal); } \\
\text { assumes } 0.75 \text {-in. pipe }\end{array}$ & 1.46 & $\mathrm{~N} / \mathrm{A}$ & $\mathrm{N} / \mathrm{A}$ & $\mathrm{N} / \mathrm{A}$ \\
\hline Total DHW waste-hot only (gal) & N/A & 0.48 & 0.28 & 0.45 \\
\hline Total DHW use-hot only (gal) & 1,212 & 497 & 72 & 109 \\
\hline \% waste DHW & 17,961 & 12,828 & 3,831 & 2,752 \\
\hline $\begin{array}{c}\text { Total water use from hot water taps } \\
\text { (gal) (includes cold water used to } \\
\text { temper DHW at tap) }\end{array}$ & $7 \%$ & $4 \%$ & $2 \%$ & $4 \%$ \\
\hline $\begin{array}{c}\text { Total water waste (gal) from hot water } \\
\text { taps }\end{array}$ & 25,078 & 18,248 & 4,102 & 4,105 \\
\hline $\begin{array}{l}\text { Flow rate highest-use fixture (gal/min } \\
\text { based on federal standards) (EPA } \\
\text { 2014) }\end{array}$ & 3,195 & 1,027 & 83 & 162 \\
\hline $\begin{array}{c}\text { Pipe diameter to highest-use fixture } \\
\text { (in.) }\end{array}$ & 2.2 & 2.2 & 2.2 & 2.2 \\
\hline $\begin{array}{l}\text { Flow speed highest use fixture (ft/s) } \\
\text { (TLV, Inc. 2015) }\end{array}$ & 0.75 & 0.75 & 0.75 & 0.75 \\
\hline Fixtures in zone & 1.32 & 1.32 & 1.32 & 1.32 \\
\hline
\end{tabular}


